\title{
PRIESTOROVÉ FORMY REZIDENČNEJ SUBURBANIZÁCIE V ZÁZEMÍ BRATISLAVY
}

\author{
Martin Šveda*, Róbert Pazúr** \\ *Univerzita Komenského v Bratislave, Prírodovedecká fakulta, Katedra regionálnej geografie, ochrany \\ a plánovania krajiny, Mlynská dolina,84215 Bratislava, martin.sveda@uniba.sk \\ **Geografický ústav SAV, Stefánikova 49, 81473 Bratislava, \\ Swiss Federal Research Institute WSL, Zürcherstrasse 111, 8903 Birmensdorf, Switzerland, geogpazu@savba.sk
}

\begin{abstract}
Spatial forms of residential suburbanization in the hinterland of Bratislava
The past two decades of suburbanization have left a tremendous footprint on the hinterland of major Slovak cities. The paper is focusing on this phenomenon from the perspective of spatial morphology - an approach to which Slovak literature has not paid much attention. The objective of this paper is to outline the spatial configuration of residential suburbanization in the hinterland of Bratislava. Through selected examples, the paper uncovers the mechanism of spatial configurations (territorial regulations, morphology of the territory, different municipal strategies, distance from Bratislava, real estate prices, etc.). Understanding the morphogenesis of new settlement structures in urban hinterland plays a key role in identifying the social, economic and environmental impacts of suburbanization. In fact, this is a vast unexplored field that needs further attention in urban studies and urban morphology in particular.
\end{abstract}

Key words: suburbanization, spatial morphology, density, landscape planning, hinterland of Bratislava, Slovakia

\section{ÚVOD}

Nárast bohatstva spoločnosti, individualizmus, ako aj prístup k zdanlivo neobmedzeným zdrojom pôdy a energií umožnili mestám, aby sa nekontrolovatel'ne „rozliali““ za hranice kompaktnej mestskej zástavby a napomohli vzniku nových priestorových foriem osídlenia (Fishman 1987 a Putnam 2000). Procesy suburbanizácie - teda presun obyvatel'stva a jeho aktivít z jadier metropolitných regiónov do ich zázemí - prebiehajú na Slovensku a predovšetkým v prímestskom regióne hlavného mesta už takmer 20 rokov (Šveda 2014 a Novotný 2016). Intraregionálna dekoncentrácia obyvatel'stva má svoje ekonomické, demografické a sociálne dôsledky, ktoré sa následne odzrkadlujuju v priestorovom usporiadaní spoločnosti (Šveda et al. 2016). Expanzia mesta do okolitej prímestskej krajiny nadobúda rozmanité formy a často ani nie je jednoduché odlišit', do akej miery ide o prirodzený (aditívny) rast mesta (urbanizáciu) a do akej miery je sídelná výstavba dôsledkom suburbanizačných tendencií. Pri diferenciácii týchto procesov sa často zdôrazňuje priestorová oddelenost' od kompaktnej mestskej zástavby, selektívny charakter migrácie (profesný a vekový) či špecifický charakter jej mechanizmov (pushfaktorov a motivácií), ktoré súvisia s túžbou bývat' vo vidieckom prostredí, no zároveň využívat' mestské funkcie ${ }^{1}$ (Ouředníček a Špačková 2013).

\footnotetext{
${ }^{1}$ Ako si všímajú Ouředníček a Špačková (2013), koncentrácia a dekoncentrácia obyvatel’stva vo vnútri metropolitných regiónov má celý rad vel'mi rozmanitých príčin, na ktorých vysvetlenie nemôžeme použit' jeden teoretický koncept. Pre pochopenie týchto procesov je nevyhnutné prihliadat' popri sledovaní kvantitatívnych ukazovatel'ov aj na širší sociálno-kultúrny kontext.
} 
Suburbanizačným procesom - predovšetkým v zázemí Bratislavy - sa v domácej literatúre venovala už značná pozornost'. Prejavy suburbanizácie sa sledovali prostredníctvom populačných procesov (Podolák 2007, Zubriczký 2010, Gajdoš a Moravanská 2011, Novotný 2011, Slavík et al. 2011 a Hudec a Tóth 2013), zmien vo využití zeme (Śveda 2011, Hanušin et al. 2013, Cebecauerová a Madajová 2015 a Pazúr et al. 2017) či bytovej výstavby (Šveda 2014 a Ondoš et al. 2017). Len menšia pozornost' sa však sústredila na morfológiu (priestorovú štruktúru) zmien prímestských oblastí (Šveda 2009). Morfologický prístup má pritom nezastupitel'né postavenie pri snahe o komplexné zhodnotenie prejavov suburbanizácie, ked’že si všíma nielen rozsah a intenzitu dekoncentračných procesov, ale aj transformáciu sídelnej štruktúry a jej sociálne, ekonomické a environmentálne dôsledky (Galster et al. 2001 a Ewing et al. 2002). Za hranicami kompaktnej mestskej zástavby vznikajú početné rezidenčné lokality, ktorých priestorová štruktúra aj vizuálne atribúty nezapadajú do existujúcich sídelných foriem. Nemôžeme ich zaradit' medzi urbánne formy, ked’že pre nižšiu hustotu zal'udnenia, absentujúci verejný priestor a rozvol'nenú (amorfnú a nekompaktnú) priestorovú štruktúru nesplńajú základné atribúty mestského prostredia. Na druhej strane nové suburbánne sídelné formy môžeme len t'ažko označit' ako rurálne, ked'že nerešpektujú prirodzenú morfogenézu vidieckych sídiel a vysoká zastavanost' pozemkov nevytvára priestor pre neurbanizované plochy (záhrady a zeleň) také typické pre vidiecke prostredie. Prilepené na okraji obce alebo umiestnené vo vol’nej krajine, tieto novovznikajúce sídelné štruktúry budú pravdepodobne ovplyvňovat' priestorovú organizáciu spoločnosti v dlhom časovom horizonte (Stanilov a Sheer 2003).

Ciel'om príspevku je zhodnotit' priestorovú konfiguráciu rezidenčnej suburbanizácie v zázemí Bratislavy a odhalit’ mechanizmy, ktoré prispievajú k formovaniu priestorových konfigurácií (územné regulatívy, morfológia územia, vzdialenost' od Bratislavy a pod.). S ciel'om identifikácie a kvantifikovania priestorových atribútov rezidenčnej suburbanizácie sa $\mathrm{v}$ príspevku zameriavame na ukazovatele hustoty zástavby, hustoty zal'udnenia a priestorového usporiadania zástavby. Domnievame sa, že pochopenie morfogenézy nových sídelných štruktúr v zázemí miest zohráva kl'účovú úlohu pri identifikácií sociálnych (sociálne interakcie medzi obyvatel'mi), ekonomických (rozvoj služieb a administratívy) a environmentálnych dôsledkov (nárast automobilovej dopravy) suburbanizácie.

Ako si všíma Stanilov (2003), pri regionálnej mierke výskumu (na úrovni administratívnych celkov) sa na suburbánne prostredie pozeráme často ako na homogénne areály, diferencované jedine na základe ich funkcie (rezidenčné - nerezidenčné). Pohl'ad v mikromierke však odhal'uje toto prostredie ako ovel'a komplexnejšie a rozmanitejšie v zmysle jeho kompozície a fyzických charakteristík. V príspevku preto využívame dve mierky prístupu: na regionálnej úrovni sledujeme základné atribúty usporiadania novej suburbánnej zástavby a dôraz kladieme najmä na hustotu a priestorovú koncentráciu. Druhá úroveň predstavuje mikromierku vybraných suburbií, kde dokumentujeme morfológiu rezidenčných lokalít s ciel'om postihnút' základné situácie formovania sídelnej štruktúry v zázemí Bratislavy.

\section{MONITOROVANIE PRIESTOROVÝCH VZOROV SUBURBÁNNEHO ROZVOJA}

Expanzia mesta do prímestskej krajiny predstavuje dynamický proces, ktorý vyvoláva komplex zmien. Zhodnotenie priestorového rozsahu či dosahov týchto 
zmien rezonuje v zahraničnej literatúre už desat'ročia (TCRP 2002, Antrop 2004 a EEA 2006). Dynamika suburbanizačných procesov prispela k vzniku mnohých medzinárodných projektov zameraných na mapovanie suburbanizácie (resp. urban sprawl) prostredníctvom snímok získavaných $\mathrm{z}$ aktívnych alebo pasívnych senzorov (radarové, letecké a satelitné snímky). Spracovaním a vyhodnocovaním získaných snímok sa monitorujú a vzájomne porovnávajú zmeny v krajinnej pokrývke metropolitných areálov. Rozsah zástavby a jej dynamiku možno na Európskej úrovni odčítat' $\mathrm{z}$ dátových vrstiev spracovaných $\mathrm{v}$ rámci viacerých projektov, ako napr. CORINE land cover, MOLAND (MURBANDY) či Urban Atlas. Využitím uvedených dátových vrstiev v kontexte monitorovania zástavby sa v domácom prostredí zaoberali viacerí autori, napr. Feranec (2008) - CORINE land cover, Kopecká a Rosina (2014) - soil sealing layer, Kopecká et al. (2015), Pazúr et al. (2017) Urban Atlas.

Popri sledovaní rozsahu zmien prímestskej krajiny má zmysel uvažovat' aj o priestorovom usporiadaní zástavby. Dostupnost' presnej lokalizácie jednotlivých objektov (budov a domov) umožňuje sledovat' suburbánny rozvoj z hl'adiska sídelnej morfológie a jej špecifických priestorových konfigurácií. Vo všeobecnosti formu zástavby (urban form) môžeme vnímat' ako priestorové usporiadanie l'udských aktivít (Anderson et al. 1996), ktoré môžeme charakterizovat' prostredníctvom hustoty, priestorovej štruktúry a diverzity (Tsai 2005). Forma zástavby môže byt' analyzovaná v rôznych geografických mierkach od regionálnej (metropolitnej), cez mierku vidieckych obcí a miest až po jednotlivé sídelné lokality. Na regionálnej úrovni môžeme uvažovat' o monocentrickej - polycentrickej, koncentrovanej rozptýlenej, súvislej - nesúvislej priestorovej štruktúre. V detailnejšej mierke jednotlivých sídiel sledujeme napr. priestorovú odl'ahlost' novej zástavby od pôvodného intravilánu obce, disperziu výstavby do vol'nej krajiny, pomer medzi novou a pôvodnou zástavbou, tzv. technomass, charakterizujúci nárast zastavanosti vo vertikálnom smere (Inostroza 2014) a pod. Je potrebné poznamenat', že uvedené ukazovatele môžu mat' odlišnú interpretáciu (a iný vplyv na l'udské aktivity) na rôznych mierkových úrovniach.

Podl'a Sýkoru a Stanilova (2014) môžeme v zázemí mesta identifikovat' dve základné hraničné situácie vymedzujúce variabilitu priestorových foriem. V prvej situácii je suburbánny rozvoj koncentrovaný v niekol'kých uzloch sídelnej siete s rovnomerným zastúpením bývania, práce a služieb. Opačný pól je charakterizovaný difúziou suburbánneho rozvoja do množstva lokalít s vysokou fragmentáciou a monofunkčným rezidenčným charakterom. Kým prvá situácia je charakteristická pre koncentrovanú decentralizáciu európskych metropolitných areálov, druhá je spájaná predovšetkým s fenoménom urban sprawl v zázemí severoamerických miest. V konkrétnych priestorových situáciách však pozorujeme vel'kú variabilitu priestorových foriem od solitérnych rodinných domov roztrúsených vo vol'nej krajine, až po kompaktné projekty bytových domov s polyfunkciou. Sčasti pritom ide o priestorové konfigurácie, ktoré sú v našom sídelnom kontexte úplne nové a doposial' nezmapované. Je pritom zrejmé, že rozdielne vzory (patterns) rozvoja sa odlišujú ich ekonomickými, sociálnymi a environmentálnymi dôsledkami (TCRP 2002). Zhodnotenie priestorového usporiadania suburbánnej zástavby prostredníctvom detailnejšej diferenciácie nám umožňuje rozlíšit' priestorové formy na škále medzi oboma uvedenými pólmi suburbánneho rozvoja.

Vzhl'adom na rozsah a intenzitu suburbanizačných procesov (resp. urban sprawl) v metropolitných regiónoch severoamerických miest nás neprekvapí, že 
práve v tomto prostredí sa najvýraznejšie rozvinul morfologický prístup sledovania priestorových atribútov suburbánnej zástavby. Suburbánny rozvoj sa v prostredí s dostatkom priestoru a minimálnych územných regulatívov prejavil prostredníctvom vytvárania rezidenčných útvarov s nízkou hustotou zástavby, vybudovaných vo vol'nej krajine bez nadväznosti na pôvodné sídelné štruktúry (leapfrog development) a s charakteristickou nepravidelnou uličnou siet’ou (amorfná uličná siet' s množstvom slepých ulíc). Suburbiá sa stali symbolom strednostavovského spôsobu života a domovom pre vel'kú čast' populácie USA (Putnam 2000).

Priestorové znaky suburbií (napr. vel'kost' a priestorové usporiadanie) sa stali objektom sledovania pomocou celého radu atribútov, ako napr. hustota priestorových jednotiek (domov), ich kompaktnost' či vzájomná nadväznost' (Ewing 1994, Torrens a Alberti 2000, Galster et al. 2001 a Frenkel a Ashkenazi 2008). Osobitná pozornost' sa venovala aj premiešaniu rezidenčnej funkcie $s$ inými funkciami (práca a služby) či formovaniu (alebo skôr absencii) lokálnych centier (Ewing et al. 2002). Ciel'om početných štúdií však nie je len kvantifikovat' „geometriu“ suburbií, ale najmä poukázat' na jej vzt'ah s množstvom sociálnych a environmentálnych ukazovatel'ov. Zvýšená energetická náročnost', znečistenie či väčší počet dopravných nehôd sú len malým výpočtom celej série negatívnych dôsledkov súvisiacich so špecifickým priestorovým charakterom severoamerických suburbií (pozri napr. Putnam 2000 a TCRP 2002). Spoločne tak narúšajú predstavu o bývaní za mestom ako o kvalitnejšom, zdravšom a bezpečnejšom prostredí pre život.

Ani v západnej Európe sa nepodarilo úplne zamedzit' negatívnym prejavom fenoménu urban sprawl, ked’že rozsiahly rozvoj predmestí sa považoval v prvom rade za znak ekonomického pokroku a nie za potenciálne vážny spoločenský problém, ktorý by bolo potrebné regulovat' (Nuissl a Rink 2005). Avšak na rozdiel od prostredia USA má rozvoj suburbánnych oblastí v Európskom prostredí koncentrovanejší priestorový charakter a vo väčšine prípadov nová výstavba nadväzuje na existujúcu sídelnú štruktúru (Van den Berg et al. 2001, Ptáček 2002 a Stanilov a Sýkora 2014). Menšie priestorové dosahy suburbánneho rozvoja, ale aj odlišná výskumná tradícia $\mathrm{v}$ európskom prostredí sústredili pozornost' na kvalitu vybudovaného prostredia, aspekty pešej dostupnosti či fragmentáciu krajiny (Hörnsten a Fredman 2000, Van Herzele a Wiedemann 2003, EEA 2006, De Clercq et al. 2007 a Ståhle 2008).

$\mathrm{V}$ tejto súvislosti sa prirodzene vynára otázka, nakol'ko sú koncepty a modely ustanovené v anglo-americkej výskumnej tradícii užitočné v prostredí metropolitných areálov strednej a východnej Európy. Aj ked' je situácia v USA v mnohých aspektoch odlišná, je zdrojom cenných skúseností a poučenia aj pre náš stredoeurópsky priestor. Najmä princípy vzniku nízkohustotných a rozvol’nených sídelných útvarov sú $\mathrm{v}$ prevažnej miere zhodné s vývojom v strednej a východnej Európe (pozri Ingram 1998).

Pri snahe o kvantifikovanie priestorových atribútov rezidenčnej suburbanizácie sa vo výskumu používa celý rad prístupov (ukazovatel'ov), ktoré môžeme roztriedit' na ukazovatele hustoty, priestorovej geometrie a dostupnosti.

\section{Hustota (zal'udnenia a zástavby)}

Ako si všíma celý rad autorov (napr. Fischman 1987, Baldassare a Wilson 1995 , Putnam 2000 a Galster et al. 2001), klúčový vplyv na kvalitu prímestského prostredia má predovšetkým hustota zal'udnenia (resp. hustota zástavby - urban density). 
V elementárnej podobe môžeme hustotu definovat' ako pomer medzi rozsahom l'udskej aktivity a plochou, na ktorej sa realizuje. Pod aktivitou nemusíme vnímat' len počet obyvatel'ov, ale aj počet bytov (domov), zamestnancov a pod. Nespochybnitel'nú pozíciu v geografickom bádaní má najmä modelovanie hustoty zal'udnenia, ktorého základy položil Clark (1951) definovaním hustotného gradientu prostredníctvom zápornej exponenciálnej funkcie (cf. Batty a Kim 1992 navrhujú použitie mocninovej funkcie).

Vyššia hustota zal'udnenia vytvára predpoklady aj na etablovanie iných funkcií než je len bývanie a tým vytvára podmienky pre vznik heterogénnejších a polyfunkčných sídiel (Haughey 2005, Ståhle 2008 a Hnilička 2012). Hustota zástavby predurčuje aj charakter automobilovej dopravy. Hustejšie zastavané lokality majú spravidla väčšiu dosiahnutel'nost' verejnej dopravy, kratšie trajektórie potrebné na dosiahnutie ciel'a (napr. zamestnania) a viaceré obmedzenia redukujúce automobilovú dopravu (Cervero a Kockelman 1997). V literatúre nájdeme k téme minimálnej (resp. optimálnej) hustoty zal’udnenia sídel (prímestských zón) množstvo zdrojov, ktorých pohl'ad je ovplyvnený sídelnými a sociálno-kultúrnymi špecifikami partikulárnych štúdiii ${ }^{2}$. Uvažovanie o špecifickej hraničnej hustote zal'udnenia má pomerne dlhú tradíciu a objavuje sa aj v domácej literatúre. Príkladom je delimitácii morfologického mesta na príklade Bratislavy (Divínsky 2000).

\section{Priestorová geometria (sub)urbánneho prostredia}

Do tejto skupiny môžeme zaradit' početnú skupinu ukazovatel'ov, z ktorých mnohé vychádzajú z ekologických princípov (Turner 1989) alebo z fraktálnej geometrie (Batty a Longley 1986). Ukazovatele ,priestorovej geometrie“ kvantifikujú dva základné atribúty urbánneho (suburbánneho) prostredia: konfiguráciu a kompozíciu (Frenkel a Ashkenazi 2008). Konfigurácia sa vzt’ahuje ku geometrii zástavby, kompozícia k úrovni heterogenity prostredia. Napríklad pre rozvol'nený rozvoj charakteru urban sprawl je typická nepravidelná, rozptýlená a fragmentovaná priestorová konfigurácia s homogénnou a segregovanou kompozíciou využitia zeme.

Konfigurácia zástavby. Z pohl'adu priestorovej konfigurácie sa v literatúre najčastejšie stretávame s ukazovatel'om kontinuity, teda spôsobu akým je (resp. nie je) nová zástavba napojená na existujúcu sídelnú štruktúru (Galster et al. 2001). Kritizuje sa najmä leapfrog development, teda výstavba nových rezidenčných štvrtí vynechaním vol'ného (nezastavaného) územia. Vol’ný priestor pôsobí nielen ako fyzická bariéra, ale aj zvyšuje celkové náklady takejto formy bývania (inžinierske siete a doprava). Casto je pritom táto separácia cieleným zámerom investora v snahe ponúknut' rezidentom vyššiu mieru súkromia a zároveň aj posilnit' význam výnimočnosti projektu. Principiálne môžeme rozlíšit’ výstavbu, ktorá prebieha oddelene

\footnotetext{
${ }^{2}$ Podl'a Newmana a Kenworthyho (1989) je hraničná hodnota približne 100 obyv./ha. Takáto hustota zal'udnenia umožňuje vznik a efektívnu prevádzku niektorých služieb a tiež aj zmysluplné využitie verejnej dopravy a občianskej vybavenosti. Ako poukazujú uvedení autori na dlhodobom globálnom výskume miest, pri hustote menšej ako 35 obyv./ha dramaticky narastá využívanie automobilovej dopravy (ako poukazujeme d’alej v príspevku, mnohé suburbánne lokality v zázemí Bratislavy nedosahujú hustotu zaludnenia ani 30 obyv./ha.). Treba však upozornit', že napriek značnému celosvetovému ohlasu sa táto štúdia nevyhla kritike, ktorá upozornila na nekompatibilitu sledovaných miest (Gordon a Richardson 1989) či agregovanie pozorovaní na národnej úrovni (Ewing a Cervero 2010). Vzt’ah medzi hustotou zástavby (zal'udnenia) a komplexnou kvalitou prostredia je nespochybnitel'ný, nedá sa však priamočiaro vyjadrit' prostredníctvom jednoduchých korelácií a aplikovat' plošne na všetky geografické situácie. Napríklad Shimek (1996) si všíma, že nárast hustoty zástavby spôsobuje len malé zníženie intenzity dopravy, Forsyth et al. (2007) nepreukázali existenciu významnejšej závislosti medzi objemom fyzickej aktivity obyvatel'ov (úrovňou zdravia) a kompaktnostou urbánnych foriem.
} 
(vynechaním nezastavanej plochy - leapfrog development), čiastočne oddelene (napojenú na zástavbu v jednom bode, tzv. bottle neck) a integrovanú (prepojenú vo viacerých uzloch s pôvodnou zástavbou).

Ďalším ukazovatel'om priestorovej štruktúry je koncentrácia, prostredníctvom ktorej sledujeme, do akej miery je stavebný rozvoj lokalizovaný disproporčne v niekol'kých miestach alebo rozš́írený rovnomerne v sledovanej priestorovej jednotke. Pri generalizovanom pohl'ade na tento ukazovatel' môžeme v domácom sídelnom kontexte rozlíšit' dve základné situácie:

1) koncentrovaná rezidenčná zástavba - vzniká prevažne ako dôsledok ucelených developerských projektov, kde investor rozparceluje väčšie územie na stavebné pozemky a bud' ich po vybudovaní inžinierskych sietí predáva individuálnym záujemcom, alebo vybuduje typizované domy. Vzhl'adom na snahu investorov o maximalizovanie profitu sa preferujú malé parcely s rozlohou cca $500-600 \mathrm{~m}^{2}$, ktoré umožňujú postavenie samostatného rodinného domu pri dodržaní minimálnych odstupových vzdialeností. Zvyšný priestor územia tvoria často len cestné komunikácie v nevyhnutnej šírke. Koncentrované formy zástavby nadobúdajú v niektorých prípadoch charakter uzavretých rezidenčných areálov (gated communities);

2) rozptýlená rezidenčná zástavba - je dôsledkom realizácie individuálnych projektov rodinných domov či menších developerských projektov. Vzniká zahust'ovaním sídelnej štruktúry v rámci intravilánu obce alebo prirodzene rozširuje zástavbu na okraji intravilánu.

Samostatným zohl'adnením ukazovatel'ov kontinuity a koncentrácie môžeme identifikovat' šest' priestorových konfigurácií suburbánnej zástavby (obr. 1).

Podl'a charakteru napojenie na pôvodnú zástavbu

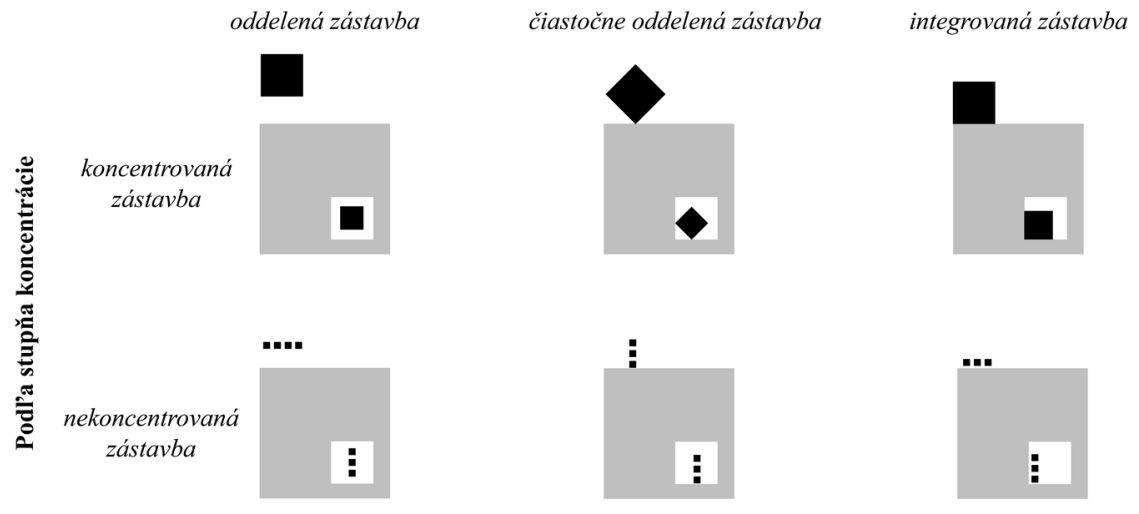

Obr. 1. Priestorová geometria novej rezidenčnej zástavby

Zdroj: vlastná schéma.

Z hl'adiska definovania priestorovej štruktúry zástavby môžeme využit' aj parametre, ktoré sa použivajú pri jej regulácii na lokálnej úrovni (v rámci územného plánovania). Medzi tieto ukazovatele môžeme zaradit' napríklad:

- koeficient podlažných plôch - pomer medzi celkovou plochou všetkých nadzemných podlaží stavby a plochou územia (pozemku), 
- koeficient zastavanosti - pomer medzi plochou zastavanou stavbami a plochou územia (pozemku),

- koeficient zelených (vegetačných) plôch - pomer medzi plochami zelene a plochou územia (pozemku).

Kombináciou uvedených ukazovatel'ov môžeme získat' nástroje, ktoré nám umožňujú rozlíšit' jednotlivé formy zástavby v pomerne detailnej mierke. Ståhle (2008) uvažuje o indexe priestorovej kompaktnosti (spatial compactness ratio), ktorý kombinuje koeficient podlažných plôch a rozsah verejného priestoru. Čím kompaktnejšie je dané územie (lokalita), tým má viac podlažných plôch a zároveň využitel'ného verejného priestoru. Výsledkom snahy o kvantitatívne zhodnotenie priestorových vzorcov zástavby je nástroj Spacemate (Berghauser a Haupt 2004). Spojením koeficientu podlažnosti, zastavanosti, nezastavaných plôch a počtu poschodí umožňujú charakterizovat' jedinečný priestorový „odtlačok“ každej lokality (obr. 2).
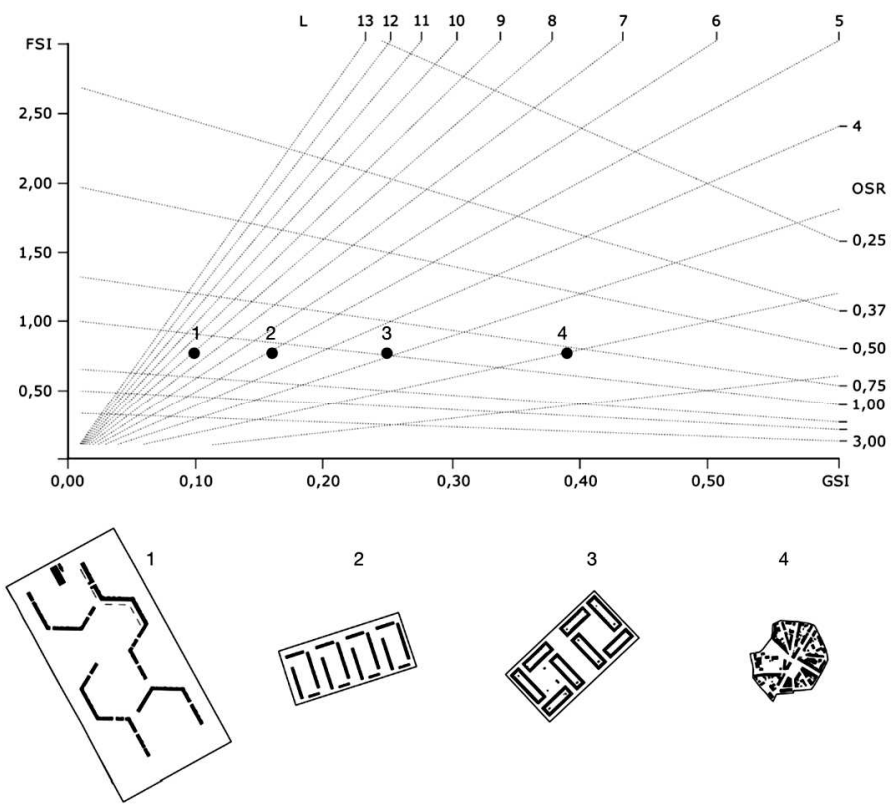

4

Obr. 2. Priestorové formy zástavby v diagrame Spacemate

Vysvetlivky: FSI - floor space index (koeficient podlažných plôch), GSI - ground space index (koeficient zastavanosti), OSR - open space ratio (koeficient verejných plôch), L - layer (priemerný počet poschodí v lokalite), 1 - vel'kobloková zástavba výškových budov, 2 - kompaktná sídlisková zástavba, 3 - bloky nájomných domov, 4 - historická zástavba centra miest.

Zdroj: Berghauser a Haupt (2004).

Kompozícia (heterogenita) zástavby: Popri hustote osídlenia a priestorovej konfigurácii je kl'účovým aspektom pri snahe o definovanie urbánneho priestoru aj heterogenita prostredia. Vytváranie monofunkčných zón bývania, ktoré prevládalo v povojnovom urbanizme, prinieslo množstvo nežiaducich dosahov, ktorých dôsledky sa v súčasnosti namáhavo snažia odstránit' mestá po celom svete, najmä však v západnej Európe a severnej Amerike (napr. práce Jane Jacobs či Jana Gehla). Heterogenita však nie je dôležitá len pre urbánne prostredie, ale rovnako sa 
dá aplikovat' aj na suburbánne zóny, v ktorých separácia rezidenčných funkcií prináša vzhl'adom na väčšie vzdialenosti ešte výraznejšie negatívne dôsledky. Funkčná heterogenita prostredia vytvára predpoklady nielen na saturovanie každodenných potrieb obyvatel'ov (služby a vol'ný čas), ale prispieva aj k vytváraniu komunitného života a vtláča lokalite jedinečný charakter - identitu miesta (Hnilička 2012). Prítomnost' služieb (napr. potravinovej predajne) môže prispiet' k redukcii dopravy a prítomnost' krajinných prvkov (napr. aleja stromov či malý park) môže posilnit' sociálne interakcie a vytvorit' dôležité prvky identity $\mathrm{v}$ inak monotónnej rezidenčnej zástavbe.

Efektívnym nástrojom na zachytenie heterogenity prostredia je analýza využitia krajiny, ktorá má v domácom kontexte bohatú výskumnú tradíciu. Údaje úhrnných hodnôt druhov pozemkov alebo leteckého (resp. satelitného) snímkovania sú užitočné na zachytenie heterogenity $\mathrm{v}$ rôznych mierkových úrovniach a v rôznych časových úsekoch.

\section{Dostupnost'}

Heterogenita prostredia úzko súvisí s dostupnost'ou aktivít, najmä však tých, ktoré sú súčast'ou každodenného života rezidentov. Spôsob, akým sú jednotlivé priestorové konfigurácie zástavby žité a vnímané rezidentmi a do akej úrovne sú prímestské lokality „mestské“ a heterogénne, môžeme skúmat’ aj prostredníctvom ukazovatel'ov založených na pešej dostupnosti (walkability) a euklidovskej geometrii (Cerverro a Kockelman 1997, Talen 2003 a Lee a Moudon 2006). Medzi frekventované ukazovatele môžeme zaradit' napríklad:

- konektivitu cestnej siete - umožňujúcu prepojenie lokálnych ciel'ov a efektívne využitie funkcií v lokalite. Popri tradičnej metrickej dížke môžeme využit' aj axiálnu mapu uličnej siete (vid' Hillier et al. 1993) a pracovat' tak aj s počtom osových obratov (axial steps). Amorfná uličná siet's množstvom slepých ulíc predlžuje nielen dížku trasy, ale zvyšuje aj počet osových obratov;

- hustotu vstupov pozdíž ulice - zachytávajúcu počet vstupov (napr. počet vstupov na 100 metrov osovej dížky ulice). Každý vstup znamená možnost' interakcie medzi súkromným a verejným priestorom (Gehl et al. 2006);

- dostupnost' rekreačnej zelene - je dôležitým atribútom kvality bývania. Napríklad vzdialenost' 300 metrov možno považovat' za limitujúcu pre každodenné využitie zelených plôch (Grahn a Stigsdotter 2003) a vzdialenost' 1000 metrov za hraničnú pre využitie lesoparkov (Hörnsten a Fredman 2000).

Pri snahe o vyjadrenie kvality prostredia prostredníctvom niekol'kých kvantitatívnych parametrov (navyše parametrov definovaných pomerne vol'ne) však musíme mat' na zreteli, že uvedené ukazovatele sú len pomocné nástroje na stanovenie určitých kvalitatívnych kritérií (sub)urbánnej zástavby. Ich interpretácia by mala zohl'adňovat' aj individuálne podmienky a lokálne špecifiká.

Hodnoty hustoty, koncentrácie, kontinuity či heterogenity nemusia nevyhnutne korelovat' s komplexnou kvalitou prostredia. Lokalita s vyššou hustotou zal'udnenia a aktivít nemusí vytvárat' kvalitnejšie prostredie pre každodenný život obyvatel'ov než lokalita s nižšou hustotou. Navyše, zvyšovanie hustoty aktivít prináša často negatívne dôsledky a je citlivo vnímaná rezidentmi (reakcie verejnosti v zmysle „NIMBY“ - not in my backyard). Nesúrodost' a protichodnost' medzi záujmami rezidentov, investorov a racionálnym využitím územia stavia samosprávu pred nel'ahké rozhodnutia. Ako kl'účové sa ukazuje dôsledné rozdelenie medzi súkromným 
a verejným priestorom, ktorým sa zamedzuje vznik ,zbytkových“ areálov degradujúcich kvalitu (sub)urbánneho prostredia a rozvol'ňujúcich zástavbu. Z pohl'adu územného plánovania je uvažovanie o hustote zal'udnenia či koeficiente zastavanosti stanovením základných regulatívov zástavby. Z geografického (syntetického) pohladu je uvažovanie o priestorových atribútoch zástavby snahou o pochopenie vzt’ahov medzi formami zástavby a organizáciou spoločnosti.

Treba však poznamenat', že analýza priestorových konfigurácií novej suburbánnej zástavby je len čiastkovým aspektom komplexnej problematiky, ked’že tému suburbánneho rozvoja nemôžeme redukovat' len na priestorové parametre rezidenčnej zástavby. Navyše, podoba suburbií je vel'mi nestála, ked’že sociálna a ekonomická energia, ktorá ich vytvára, sa rýchlo presúva do nových a vzdialenejších priestorov. V situácii, ked' absentuje pevnejší konceptuálny rámec, je prílišná pozornost' venovaná len súčasným formám suburbánneho priestoru v zmysle ,tabula rasa“ ignorovaním vývoja suburbií v čase (Vaughan et al. 2009).

\section{VÝCHODISKÁ REZIDENČNEJ SUBURBANIZÁCIE V ZÁZEMÍ BRATISLAVY}

Na problematiku suburbanizácie (resp. dekoncentrácie) sa často pozeráme cez optiku a skúseností z angloamerického prostredia. Súčasný globálny rozvoj metropolitných území však prináša vel'mi rozdielne skúsenosti so suburbanizáciou, ktorej priestorové formy sa líšia naprieč politickým, ekonomickým a kultúrnym kontextom. Táto neusporiadaná mozaika sa stala typickým znakom nielen pre metropolitné areály západného sveta, ale aj pre zázemie mnohých miest v Afrike, Ázii a Južnej Amerike (Sýkora a Stanilov 2014). Ako si všíma celý rad autorov (Hirt 2007, Borén a Gentile 2007, Leetmaa et al. 2009 a Ouředníček a Pospíśilová 2016), osobitné postavenie majú postsocialistické mestá strednej a východnej Európy, ktorých spoločenský a ekonomický vývoj charakteristický dynamickými zmenami priniesol do sídelnej štruktúry špecifické situácie formujúce súčasný sídelný rozvoj.

Pomerne hustá sídelná siet' v zázemí slovenských miest bola poznačená v období socializmu centrálnym riadením výstavby a koncentrovaním rozvoja do strediskových obcí (Ištok a Klamár 2005). Mnohé populačne prestarnuté a infraštruktúrne poddimenzované obce s výhodnou geografickou polohou sa stali po páde socialistického režimu prirodzeným ciel'om extenzívneho rozvoja rezidenčnej suburbanizácie. Ich pozvol'ný rast prostredníctvom individuálnych projektov koncom 90. rokov vystriedala často živelná výstavba rozsiahlych rezidenčných areálov. Najdynamickejší vývoj v rámci Slovenska prebehol práve v zázemí Bratislavy (Šveda 2014). V období rokov 1996 - 2015 sa dokončilo v zázemí mesta približne 37000 bytových jednotiek (obr. 3) a populačná vel'kost' narástla o vyše 54000 obyvatel'ov (SÚ SR 2016). Uvedený objem imigrácie je však pravdepodobne väčší, ked’že čast' migrantov štatistika nezohl'adňuje $\mathrm{e}^{3}$. Viaceré obce v zázemí Bratislavy v uplynulom desat'ročí zdvojnásobili počet obyvatel'ov a výmeru zastavanej plochy (tab. 1). Tento extenzívny rast vidieckych sídiel pritom nemá v sídelnom vývoji Slovenska

\footnotetext{
${ }^{3} \mathrm{~V}$ dôsledku neochoty prist'ahovalcov registrovat' si nové miesto trvalého pobytu dochádza k značnému skresleniu v evidencii obyvatel'stva (Šveda a Podolák 2014). Pri zohl'adnení objemu bytovej výstavby sa do zázemia Bratislavy mohlo za uplynulých 20 rokov prest’ahovat’ až 80-tisíc nových rezidentov.
} 
obdobu (paralely by sme mohli nájst' jedine s výstavbou robotníckych kolónií v blízkosti vel'kých priemyselných centier v minulom storočí).

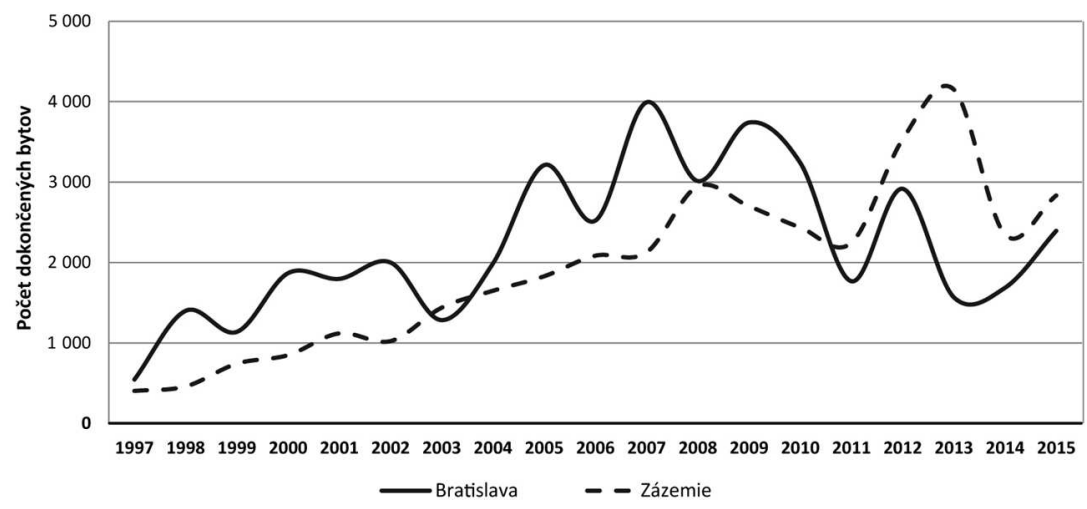

Obr. 3. Bytová výstavba vo funkčnom mestskom regióne Bratislava v období rokov $1997-2015$

Zdroj údajov: ŠÚ SR (2016).

Tab. 1. Nárast zastavaných plôch a počtu obyvatel'ov vo vybraných obciach v zázemí Bratislavy.

\begin{tabular}{lcccc}
\hline Obec & $\begin{array}{c}\text { Zastavaná plocha } \\
2002(\mathrm{ha})\end{array}$ & $\begin{array}{c}\text { Zastavaná plocha } \\
2013(\mathrm{ha})\end{array}$ & $\begin{array}{c}\text { Počet obyvatel'ov } \\
2002\end{array}$ & $\begin{array}{c}\text { Počet obyvatel'ov } \\
2013\end{array}$ \\
\hline Chorvátsky Grob & 106 & 148 & 1658 & 4415 \\
Marianka & 31 & 48 & 969 & 1523 \\
Dunajská Lužná & 144 & 167 & 2979 & 5050 \\
Bernolákovo & 215 & 266 & 4666 & 5814 \\
\hline
\end{tabular}

Zdroj: GKÚ (2013) a ŠÚ SR (2016).

Extenzívna privatizácia a príležitosti transformujúcej sa ekonomiky, ako aj narastajúca sociálno-ekonomická polarizácia a zmeny v preferenciách v bývaní, priniesli nové vzory v dopyte a produkcii bytovej výstavby. Narastajúca polarizácia vyplývajúca $\mathrm{z}$ rozdielneho zhodnotenia lokality na základe trhových princípov sa stala hlavným stimulom prispievajúcim k transformácii urbánnych a suburbánnych štruktúr v zázemí Bratislavy. Popri gentrifikácii, urbánnej revitalizácii a sociálnej segregácii sa rezidenčná suburbanizácia stala jedným z najviditel'nejších dôsledkov novej valorizácie (sub)urbánneho prostredia (Tammaru 2001, Sýkora a Stanilov 2014 a Šveda a Šuška 2014).

V pôvodne (sociálne a ekonomicky) relatívne homogénnych vidieckych obciach vzniká prílevom nového obyvatel'stva vel'mi pestrá sociálna a kultúrna mozaika, ktorá nadobúda rozličné priestorové (vizuálne) formy - od uzavretých luxusných rezidencií vyšších spoločenských vrstiev, cez sociálne zmiešané lokality až po ekonomicky dostupnejšie bytové domy a radovú zástavbu $\mathrm{v}$ menej atraktívnych (lukratívnych) častiach zázemia. Ako si všíma rad autorov, pre čast' migrantov je bývanie v zázemí naplnením „suburbánneho sna“, zatial' čo pre iných je dôsledkom pragmatického riešenia bývania (Potočný 2006, Galčanová 2013 a Śveda 2016). 
Predpokladáme, že tieto rozdielne motivácie sa do určitej miery prejavujú aj vo formách suburbánnej zástavby.

Proces suburbanizácie nestimuluje len túžba po naplnení individuálnych predstáv o bývaní, ale aj fenomény postsocialistickej transformácie. Osobitné postavenie $\mathrm{v}$ stredoeurópskom priestore má najmä proces reštitúcií, ktorý priniesol nové nerovnosti v transformujúcej sa spoločnosti (Glock et al. 2007). Význam reštitúcií spočíva najmä v jeho potenciáli transformovat' vlastnícke vzorce, a teda aj zmenit' sociálno-priestorovú štruktúru. Reštitúcie pôdy pôvodným vlastníkom a formujúci sa realitný trh priniesli možnost' rýchlej kapitalizácie vlastníctva pôdy. Z časti pasívnych príjemcov štátom pridel'ovaných bytov sa stali aktívni aktéri na trhu s nehnutel'nost’ami, ktorí rýchlo rozšírili svoje záujmy aj o investovanie v suburbánnom priestore (Sýkora a Stanilov 2014). Pol’nohospodársky využívané plochy v zázemí mesta sa tak počas krátkeho obdobia stali atraktívnym priestorom na uspokojenie narastajúcich priestorových, ale aj kvalitatívnych nárokov na bývanie. $\mathrm{V}$ časovo náročnom a komplikovanom procese reštitúcií sa pôda vracala reštituentom len postupne, čo ovplyvnilo aj možnosti a dynamiku výstavby nových rezidenčných lokalít. Napríklad ucelené vysporiadanie pozemkov v obci Chorvátsky Grob umožnilo rýchly rozvoj najväčšieho suburbia v zázemí Bratislavy (lokalita Čierna Voda). Rekonštrukcia pozemkového vlastníctva sa výrazne podiel'a aj na disperzii rezidenčnej suburbanizácie v množstve menších lokalít. Podobné tendencie môžeme pozorovat' aj v iných postsocialistických krajinách (cf. Tammaru et al. 2009 a Ouředníček 2007).

Na suburbánne trendy v bývaní možno pozerat' aj cez optiku širších globalizačných zmien, ktoré prinášajú impulzy nerešpektujúce vývojovú trajektóriu a kultúrno-historickú tradíciu sídelného vývoja. Len t’ažko by sme hl'adali historickú paralelu k súčasným rezidenčným projektom, ktoré prinášajú do sídelného priestoru nové formy. Uličná siet's množstvom slepých ulíc, „súkromné“ ulice a „citadely“, či redukcia verejného priestoru na príjazdovú komunikáciu k domu, sú nové znaky priestorovej štruktúry rezidenčných lokalít.

\section{METÓDY A DÁTA}

Priestorovú konfiguráciu novej bytovej výstavby sme hodnotili na základe podkladov z dátovej vrstvy ZBGIS (Základná báza údajov pre geografický informačný systém, 2013). ZBGIS tvoria geometrické údaje o priestorovom usporiadaní objektoch v krajine, ich tematických atribútov a vzájomných väzbách. Pre účely analýzy sme pracovali s triedami objektov „rodinný dom“ a „bytový dom“ (pozri katalóg tried objektov ZBGIS 2013), spojenými do pracovnej triedy rezidenčných jednotiek. Rezidenčné jednotky tak zahŕňali samostatné rodinné domy, dvojdomy, domy $\mathrm{v}$ radovej zástavbe a bytové domy. Ked’že databáza ZBGIS neobsahuje údaje o roku výstavby jednotlivých domov, na identifikovanie novopostavených domov sme použili ortosnímky datované $\mathrm{k}$ roku 2003. Takto extrahované objekty vytvárajú kompletný súbor novopostavených domov v období rokov 2003 - 2012 poskytujúci relatívne spol'ahlivý obraz o transformácii sídelnej štruktúry a rozsahu novej zástavby v zázemí Bratislavy.

$\mathrm{Na}$ hodnotenie priestorovej heterogenity sme využili Moranov index priestorovej autokorelácie (d’alej MI) predstavujúci štandardizované priestorové vyjadrenie nepriestorového koeficientu korelácie medzi skúmanými hodnotami v určitých úrovniach susedstva (O’Sullivan a Unwin 2002, Shortridge 2007 a Pazúr et al. 
2012) vyjadrujúc tak zhlukovitost', rozptýlenost' alebo náhodnost' skúmaného javu. Z hl'adiska interpretácie indikujú kladné hodnoty Moran I indexu celkovú pozitívnu závislost' a záporné hodnoty celkovú negatívnu závislost' skúmaného javu, pričom o dokonalej pozitívnej, resp. negatívnej závislosti možno hovorit' pri hodnotách blízkych \pm 1 . Absenciu akejkol'vek priestorovej závislosti, t. j. náhodnost' skúmaného javu, zasa vyjadruje hodnota blízka 0 (Pazúr et al. 2012). V tomto prípade sme pomocou MI zhodnotili priestorové usporiadanie novej rezidenčnej výstavby (obr. 4).

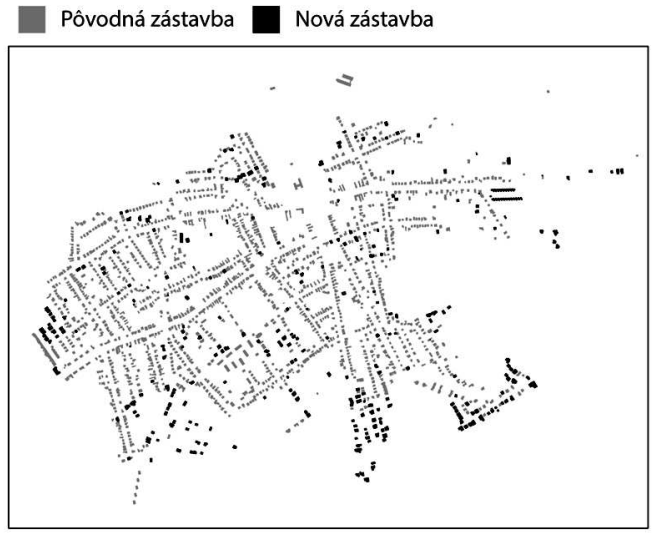

Moran $I=0,38$

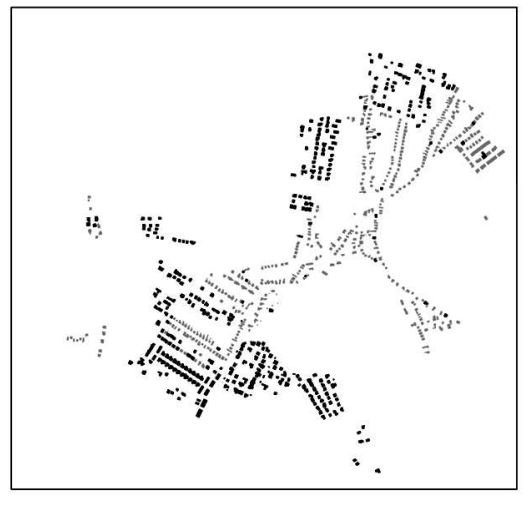

Moran $I=0,78$

Obr. 4. Moranov index priestorovej autokorelácie na príklade dvoch obcí v zázemí Bratislavy

vl'avo - Ivanka pri Dunaji, vpravo - Malinovo

Ďalej sme v príspevku použili údaje o bytovej výstavbe, ktorú eviduje Štatistický úrad SR. Evidencia bytovej výstavby obsahuje nielen údaje o dokončených bytoch, ale aj počty vydaných stavebných povolení a podlahovú či obytnú plochu bytov. Výhodou týchto údajov je ich vysoká presnost', ked’že sú produktom stavebného konania a nie sú závislé od individuálneho nahlasovania počas celonárodného cenzu.

Plošná vel'kost' zastavaných areálov bola získaná z databázy Úhrnných hodnôt druhov pozemkov (ÚHDP), ktorú spravuje Geodetický a kartografický ústav (GKÚ 2013). Pri pracovaní s databázou ÚHDP treba brat' do úvahy aj niektoré špecifické vlastnosti týchto dát a zohl'adnit' ich pri interpretácii. Ako si všíma Feranec (2008), medzi právnym stavom a skutočným využívaním krajiny môžu existovat' pomerne značné rozdiely.

$\mathrm{Na}$ porozumenie mechanizmom formovania koncentrovaných a rozptýlených foriem zástavby sme použili záznamy o vlastníckej štruktúre z Mapového portálu katastra nehnutel'ností. Táto webová mapová aplikácia slúži na interaktívnu prácu s údajmi ZBGIS a digitálnymi údajmi katastra nehnutel'ností (napr. náhl'ady listov vlastníctva).

Priestorový rámec analýzy tvorí funkčný mestský región Bratislava (regionálny systém „FMR 01-A“) vymedzený na základe koncepcie denných urbánnych systé- 
mov (Bezák 2014), ktorý tvorí 111 obcí s počtom obyvatel'ov 660 tisíc. Konštrukcia funkčných mestských regiónov je odrazom priestorových a funkčných vzt'ahov medzi mestom a jeho zázemím vyjadrenej prostredníctvom dochádzky za prácou. Takto konštruované regióny sú vhodné na sledovanie komplexných procesov koncentrácie (urbanizácie), resp. dekoncentrácie (suburbanizácie). Vzhl'adom na nesúlad medzi administratívnym vymedzeným hraníc Bratislavy a reálnym rozsahom mestskej zástavby sme od jadra funkčného mestského regiónu odčlenili mestské časti s prevažne vidieckym charakterom zástavby a tým sme zúžili jadro na kompaktné mesto s relatívne súvisle zastavaným územím (cf. Divinský 2000, Šveda 2014 a Novotný 2016). Do zázemia Bratislavy tak boli zaradené aj mestské časti Čunovo, Devínska Nová Ves, Devín, Jarovce, Rusovce a Záhorská Bystrica.

\section{HUSTOTA ZÁSTAVBY A ZALUUNENIA V REGIONÁLNEJ A LOKÁLNEJ MIERKE}

Základný obraz o priestorovej distribúcii jednotiek rezidenčnej suburbanizácie (rodinných a bytových domov identifikovaných v období v rokoch 2003 - 2012) poskytuje obr. 5. Odhad jadrovej hustoty (kernel density) umožňuje transformáciu diskrétnych bodových javov na spojitú plochu hustoty a jeho aplikácia na študované územie poukazuje na dve jadrá koncentrujúce najväčší objem výstavby v zázemí mesta. Primárne jadro výstavby sa nachádza v priestore medzi Chorvátskym Grobom a Dunajskou Lužnou, sekundárne jadro sa formuje v okolí mesta Stupava. Neprekvapí, že tvar gradientu je pretiahnutý v smere hlavných dopravných koridorov smerujúcich do Bratislavy a že pravidelný tvar koncentrických zón je narušený bariérou Malých Karpát. Treba však upozornit', že deformity v tesnej blízkosti jadrového mesta sú spôsobené ignorovaním výstavby v rámci kompaktnej mestskej zástavby Bratislavy. V tejto mierke je zaujímavá predovšetkým disproporcia medzi východnou a severovýchodnou čast’ou zázemia Bratislavy. Nižšiu intenzitu rezidenčnej výstavby v Záhorskej časti Bratislavského zázemia možno pravdepodobne pripísat' nižšej dostupnosti pozemkov a atraktivite prostredia. Každopádne aj tento priestor sa v ostatnom období výrazne dynamizuje (rozsiahlejšie rezidenčné projekty v lokalite Bory, v Záhorskej Bystrici či v Stupave), čo môže súvisiet' aj s určitou saturáciou rezidenčnej výstavby vo východnej časti zázemia Bratislavy (Rovinka, Most pri Bratislave, Chorvátsky Grob a pod.) a akumuláciou negatívnych dôsledkov suburbánneho rozvoja - najmä narastajúcej intenzity dopravy.

$\mathrm{Na}$ hustotu rezidenčných jednotiek priamo nadväzuje aj hustota zal'udnenia. Vo väčšine suburbanizovaných obcí bol zaznamenaný nárast počtu obyvatel'ov na jednotku zastavanej plochy. Výrazné zvýšenie hustoty dosiahli najmä obce Chorvátsky Grob, Dunajská Lužná, Rovinka, Malinovo či Zálesie (obr. 5). Zmenu hustoty zal'udnenia zaznamenali prakticky všetky obce v tesnom zázemí Bratislavy. K analogickým zisteniam dospeli aj Hudec a Tóth (2013), avšak s použitím odlišnej metodiky. Na druhej strane spektra sa pokles hustoty zal'udnenia týkal najmä obcí ležiacich pri Dunaji a na Záhorí. Tento pokles je však do vel'kej miery spôsobený reklasifikovaním ${ }^{4}$ niektorých areálov v okolí vodného diela Gabčíkovo a zmenami v evidencii pozemkov v oblasti vojenského obvodu Záhorie ${ }^{5}$. Prejavujú sa tak limi-

\footnotetext{
${ }^{4}$ Z kategórie „ostatná plocha“ na kategóriu „zastavané plocha a nádvoria“ a kategóriu „,vodná plocha".

${ }^{5}$ Medzi rokmi 2002 - 2013 došlo k úbytku rozlohy vojenského obvodu Záhorie o približne 10 km².
} 
ty použitej metodiky pracujúcej s kategóriami využitia zeme (ÚHDP), a preto je potrebné brat' uvedené zistenia so značnou interpretačnou rezervou.

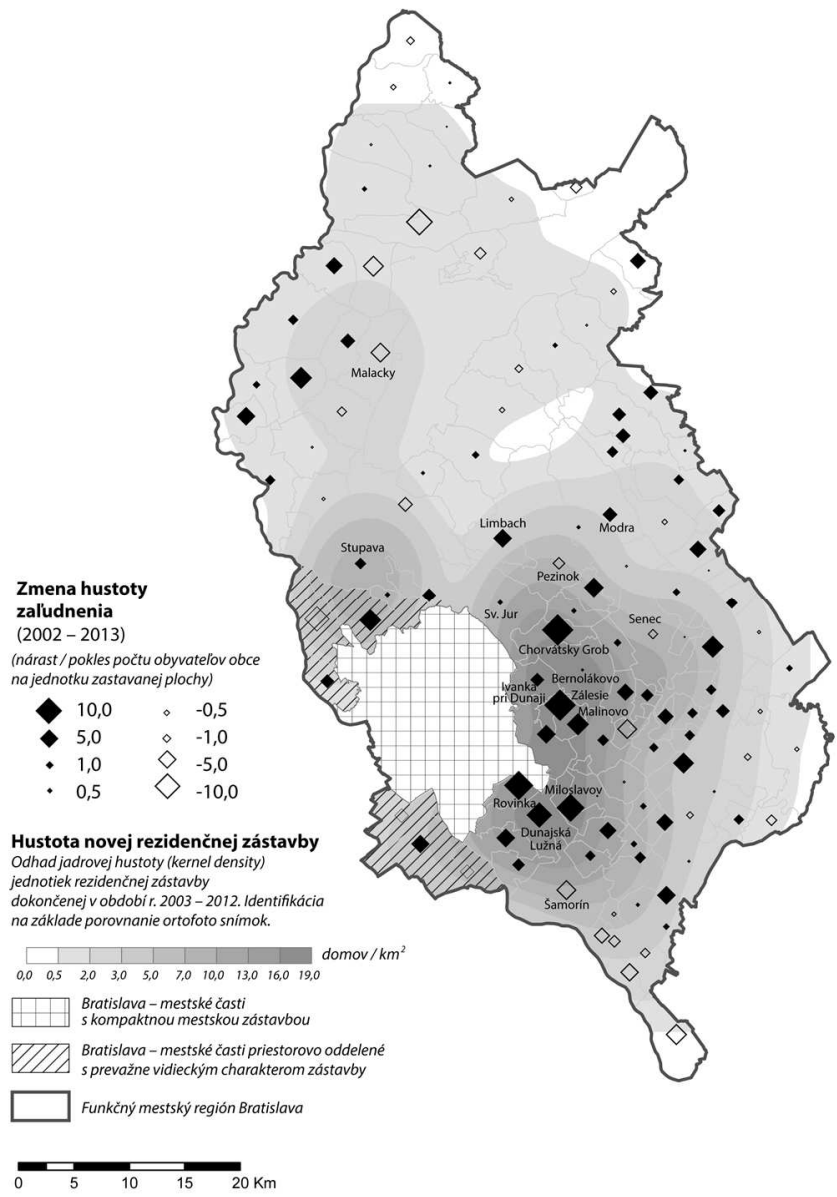

Obr. 5. Zmena hustoty zal’udnenia v obciach Funkčného mestského regiónu Bratislava a odhad jadrovej hustoty novej rezidenčnej zástavby v zázemí Bratislavy.

Zdroj: GKÚ (2013 a 2014), vlastné spracovanie.

Výsledky bližšie realite suburbií dostaneme pri prerátaní počtu obyvatel'ov vzhl'adom na plochu intravilánu obcí. V súvislosti s nesúladom medzi právnym stavom a reálnym rozsahom zastavaného územia sme využili letecké snímky datované k rokom 2003 a 2015, v rámci ktorých sme vyhraničili areály reprezentujúce zastavané územie obce (vrátane vnútorných cestných komunikácií, priliehajúcich záhrad, plôch zelene, technickej a občianskej vybavenosti). Tabul'ka 2 zachytáva zmenu hustoty zal'udnenia $\mathrm{v}$ rámci kompaktne zastavaného územia obce pre vybrané mestské časti Bratislavy (s vidieckym charakterom zástavby) a pril’ahlé obce v tesnom zázemí Bratislavy. Z uvedených príkladov môžeme pozorovat', že napriek hustej parcelácii a vysokej zastavanosti nedochádza k výraznejšiemu nárastu 
hustoty zal'udnenia (dokonca aj pri zohl'adnení obyvatel'ov neprihlásených na trvalý pobyt). Vo viacerých obciach môžeme dokonca pozorovat' pokles hustoty zal'udnenia. Táto situácia reflektuje nové rozvol'nené formy zástavby, ktoré „rozried’ujú“ pôvodne kompaktné zastavané územie obcí.

Tab. 2. Hustota zal'udnenia v rámci kompaktne zastavaného územia obce pre vybrané mestské časti Bratislavy (s prevažujúcim vidieckym charakterom zástavby) a pril’ahlé obce $v$ tesnom zázemí Bratislavy (stav k roku 2003 a 2015)

\begin{tabular}{lcclcc}
\hline \multirow{2}{*}{ Obec } & \multicolumn{2}{c}{$\begin{array}{c}\text { Hustota zal'udnenia } \\
\text { (obyv./ha) }\end{array}$} & Obec & \multicolumn{2}{c}{$\begin{array}{c}\text { Hustota zal'udnenia } \\
\text { [obyv./ha] }\end{array}$} \\
\cline { 2 - 3 } & 2003 & 2015 & & 2003 & 2015 \\
\hline Bratislava-Čunovo & 22 & 21 & Bernolákovo & 18 & 19 \\
Bratislava-Devínska Nová Ves & 84 & 73 & Dunajská Lužná & 20 & 17 \\
Bratislava-Devín & 23 & 16 & Hamuliakovo & 17 & 17 \\
Bratislava-Jarovce & 19 & 19 & Chorvátsky Grob & 23 & 20 \\
Bratislava-Rusovce & 19 & 23 & Ivanka pri Dunaji & 23 & 24 \\
Bratislava-Záhorská Bystrica & 11 & 15 & Kalinkovo & 19 & 17 \\
Borinka & 10 & 10 & Malinovo & 17 & 15 \\
Lozorno & 21 & 20 & Miloslavov & 9 & 11 \\
Marianka & 15 & 13 & Most pri Bratislave & 18 & 18 \\
Stupava & 23 & 23 & Rovinka & 21 & 32 \\
Zohor & 31 & 30 & Zálesie & 13 & 15 \\
Svätý Jur & 46 & 39 & & & 15 \\
\hline
\end{tabular}

Zdroj: ŠÚ SR (2016), GKÚ (2013), vlastné výpočty.

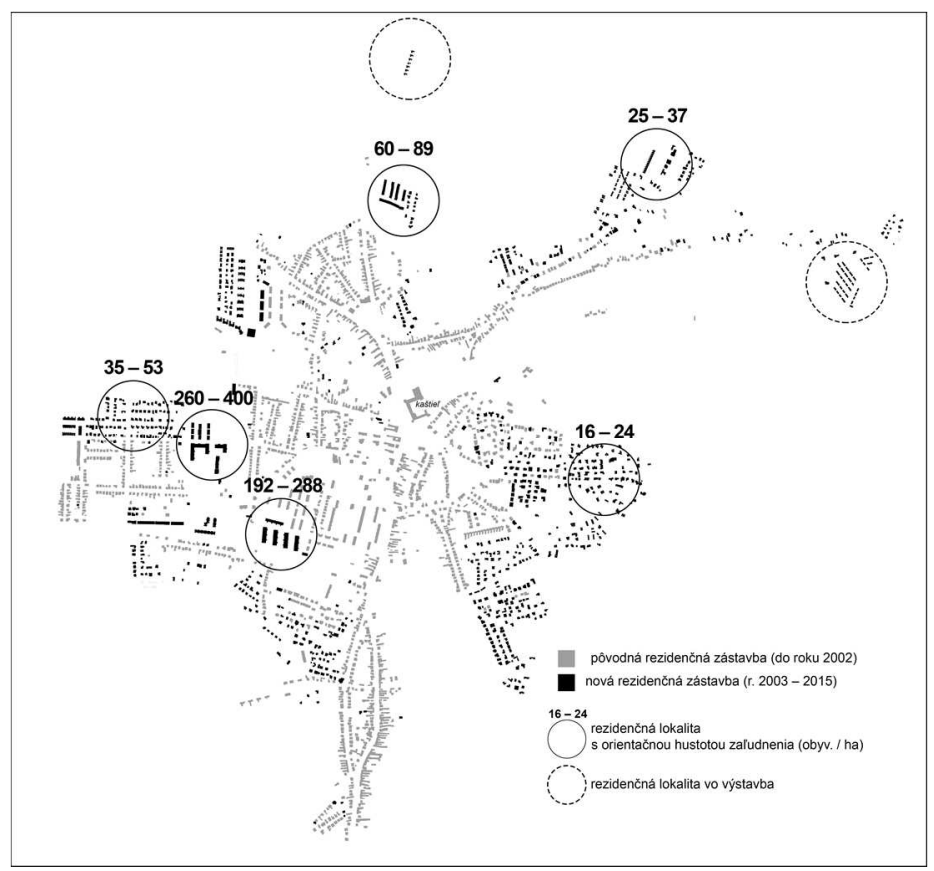

Obr. 6. Nová rezidenčná zástavba a odhad hustoty zal'udnenia vybraných rezidenčných lokalít v meste Stupava

Zdroj: GKÚ (2013), vlastné výpočty. 
Pri pohl'ade na hustotu zal'udnenia $\mathrm{v}$ mierke jednotlivých areálov pozorujeme značné diferencie. Môžeme ich dokumentovat' na príklade mesta Stupava (obr. 6). Suburbánny rozvoj sa v meste prejavuje nielen výstavbou kolónií rodinných domov, ale aj početnými projektami bytových domov. Práve v týchto areáloch, kde hustota zal'udnenia dosahuje vyššie hodnoty, sa formuje heterogénnejšie prostredie s rozmanitejšími funkciami a funkčným verejným priestorom (ihrisko, zelené plochy a menšie prevádzky služieb). V Stupave však nachádzame aj husto obývané rezidenčné areály, ktoré neprinášajú popri bývaní iné funkčné využitie a len využívajú vybavenost' $\mathrm{v}$ rámci pôvodnej zástavby. V prípade priestorovo izolovaných rezidenčných areálov je ich zmysluplné napojenie na sociálnu infraštruktúru (školy, zdravotnícke zariadenia, športoviská a pod.) značne limitované.

\section{TYPY PRIESTOROVEJ KONFIGURÁCIE SUBURBÁNNEJ ZÁSTAVBY}

Charakteristickým prejavom suburbanizácie v prímestskej krajine je formovanie osobitných sídelných útvarov - suburbií, ktoré z viacerých aspektov predstavujú nový prvok v morfológii sídelnej štruktúry. Ako uvádza Ouředníček (2002), používanie termínu suburbium je v odbornej literatúre vynútené snahou odlíšit' suburbium od štandardného predmestia (angl. suburb). V slovenskom kontexte za suburbium môžeme považovat' priestorovo samostatné sídlo v zázemí (jadrového) mesta, od ktorého je závislé prostredníctvom pohybu za prácou a služieb. Vzniká často ako ucelený rezidenčný projekt na okraji obce alebo aj vo vol'nej krajine. Pre suburbium je charakteristická hustá parcelácia, množstvo slepých ulíc či amorfná uličná siet'. Ich sídelná morfológia často kontrastuje so staršou zástavbou, ktorej základné tvary sú výsledkom skôr pozvol'ného rozrastania, rešpektujúceho reliéfne podmienky a funkčné potreby (pol’nohospodárskych) sídiel. Kým v minulosti sa vidiecke sídla vytvárali prirodzenou adíciou nových domov na okraji intravilánu, sídelná štruktúra suburbií je vtlačená do územia v značnom predstihu. Napriek odlišnej morfogenéze identifikácia suburbií v konkrétny priestorových situáciách však nemusí byt' jednoznačná. V dynamicky sa meniacom prostredí predmestí sa pôvodne oddelené sídla prepájajú novšou zástavbou a pribúdajú aj nerezidenčné formy využitia zeme (obchody a iné služby), ktorých posilnenie znižuje závislost' na jadrovom meste a prispieva $\mathrm{k}$ formovaniu funkčne rozmanitejších a teda aj sebestačnejších sídiel (tzv. edge cities).

Suburbiá vznikajú prevažne ako ad hoc rezidenčné zóny s pomerne koncentrovanou zástavbou a ostrými hranicami (nezastavaná plocha, ploty jednotlivých parciel či vonkajšie oplotenie celej rezidenčnej zóny), ktoré ich v priestore pomerne zretel'ne delimitujú. Túto priestorovú koncentráciu môžeme zjednodušene identifikovat' prostredníctvom priestorovej autokorelácie. Aplikovaním Moranovho indexu priestorovej autokorelácie (d’alej Moran I) na rezidenčné jednotky v rámci jednotlivých obcí vyjadrime ich priestorovú distribúciu jedným číslom. Obr. 7 zachytáva priestorové diferencie $\mathrm{v}$ koncentrácii novej rezidenčnej zástavby vyhodnotené aplikovaním Moran I. Je zrejmé, že koncentrovaná forma výstavby (ucelené projekty developerov) dominuje prevažne v obciach v tesnom zázemí Bratislavy, zatial' čo vo vzdialenejších častiach zázemia prevláda nekoncentrovaná výstavba (individuálne realizácie rodinných domov). Pás koncentrovanej rezidenčnej zástavby tvoria suburbiá rôzneho charakteru, priestorovej konfigurácie a s rozličným stupňom napojenia na pôvodnú zástavbu. 


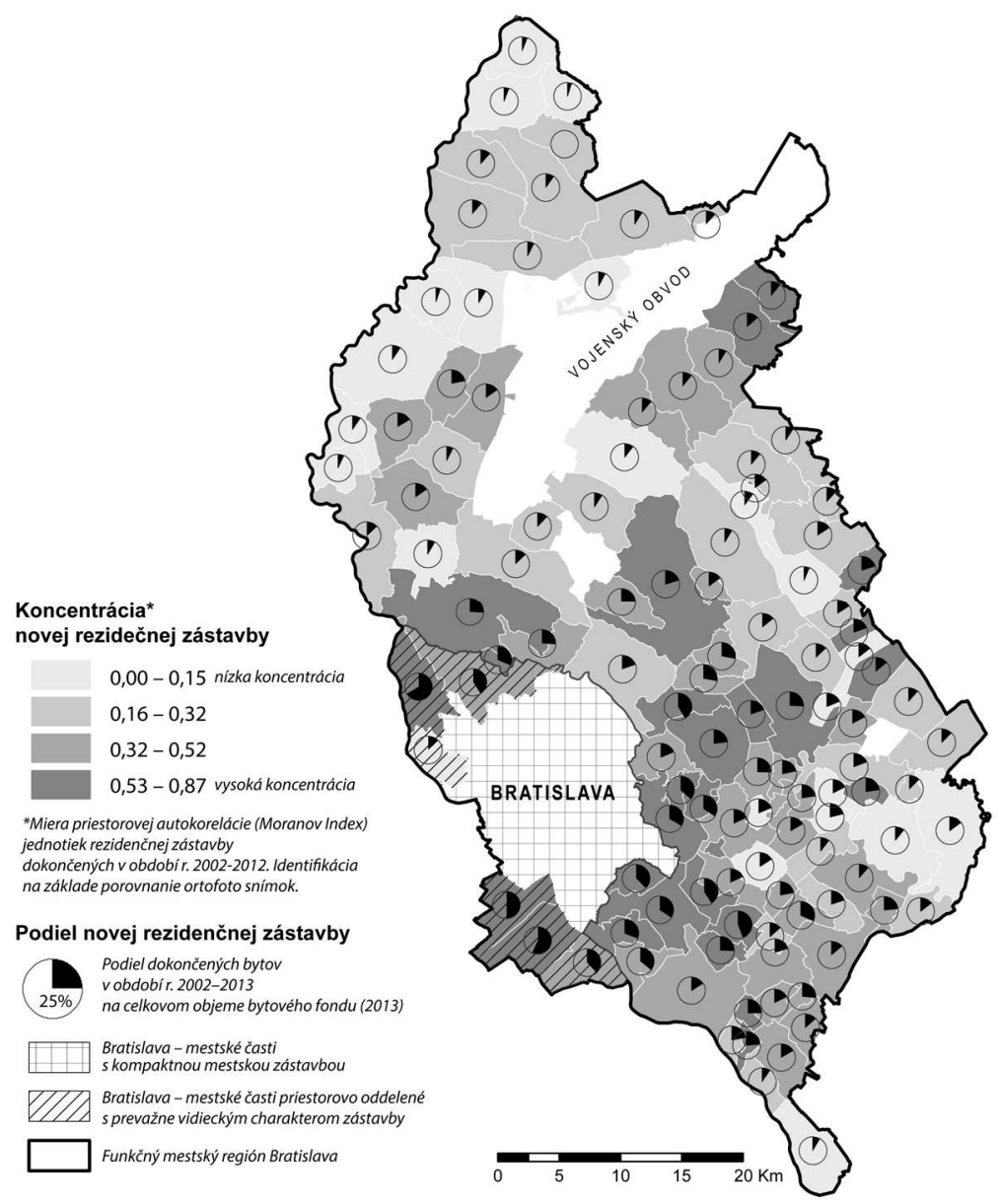

Obr. 7. Koncentrácia novej rezidenčnej zástavby v zázemí Bratislavy Zdroj: GKÚ (2013), ŠÚ SR (2016) a vlastné spracovanie.

Popri koncentrácii môžeme d'alej sledovat' aj priestorovú konfiguráciu suburbánnej zástavby v zázemí Bratislavy v zmysle uvedenej typológie (obr. 8). Pri koncentrovanej výstavbe môžeme pozorovat', že napojenie nových rezidenčných zón na pôvodnú sídelnú štruktúru je v početných prípadoch redukované len na úzke hrdlo jednej prístupovej komunikácie (tzv. bottle neck, obr. 9). Časté je aj formovanie koncentrovanej zástavby (suburbií) vo vol'nej krajine bez nadväznosti na pôvodnú sídelnú štruktúru (Studené - Most pri Bratislave, Malý Raj - Slovenský Grob). K posilneniu separácie dochádza aj prostredníctvom osadenia zákazovej značky (informujúce návštevníkov, že prichádzajú na súkromný pozemok) či uzavretia lokality bránou alebo rampou. V ojedinelých prípadoch sa objavuje aj fenomén ,full service housing“", ktorý predstavuje nadštandardné bývanie zabezpečujúce vysokú mieru súkromia, bezpečia (uzavretý areál chránený strážnou službou alebo kamerovým systémom) a komplexnú správu rezidenčného areálu (napr. starostlivost' o zeleň, údržba komunikácií a pod.). Príkladom sú napr. lokality Záhor- 
ské sady ${ }^{6}$ (Záhorská Bystrica), Malý Raj (Slovenský Grob) a pod. Napriek početným suburbiám vybudovaným na ,zelenej lúke“ sme však doposial' neboli svedkami ich odštiepenia od materskej obce. V tomto kontexte sú mechanizmy umožňujúce vznik administratívne samostatných sídiel značne rigidné. Podl'a Stanilova (2007) je však len otázkou času, kedy sa naštartuje proces delenia metropolitnej sídelnej štruktúry v krajinách strednej a východnej Európy.

Suburbánny rozvoj prostredníctvom koncentrovanej výstavby sa však nerealizuje celoplošne vo všetkých obciach v zázemí Bratislavy. Napríklad v katastrálnom území mesta Svätý Jur, alebo v prímestskej obci Ivanka pri Dunaji, má nová výstavba prevažne rozptýlený charakter. Prirodzene sa tak ponúka otázka, prečo sa v niektorých lokalitách neformujú kompaktné suburbiá. Na základe analýzy konkrétnych situácií v obciach s rozptýleným charakterom zástavby môžeme identifikovat' niekol'ko možných príčin:

- Priestorové bariéry. Neumožňujú extenzívny priestorový rast. Môže íst' o hranicu chránených prírodných areálov alebo nadradenej dopravnej infraštruktúry (železnica a dial'nica). Príkladom je mesto Svätý Jur (Malé Karpaty, Jurský Súr a železnica) alebo mestská čast’ Devín (rieka Dunaj a Devínska Kobyla).

- Rozdrobená vlastnícka štruktúra pozemkov. Scel'ovanie parciel je časovo a finančne nesmierne náročný proces. Mozaikovitú štruktúra parciel nachádzame najmä vo vinohradoch, alebo na okraji intravilánov obcí (na mieste bývalých záhumienkov). Napriek tomu $\mathrm{v}$ niektorých atraktívnych lokalitách investori skupujú jednotlivé parcely a postupne tak formujú areály pre d'alšiu výstavbu (vid' obr. 10).

- Nevysporiadané pozemky, cirkevná a obecná pôda. V prípade nezastavaných väčších parciel ide často o cirkevnú pôdu (Ivanka pri Dunaji) alebo pozemky vo vlastníctve samosprávy (napr. Svätý Jur - značnú čast' vinohradov v bezprostrednom kontakte s intravilánom vlastní samotné mesto). Môžeme predpokladat', že správanie týchto vlastníkov je na realitnom trhu odlišné od súkromných spoločností alebo fyzických osôb. Svoju úlohu zohrávajú aj nevysporiadané reštitučné nároky. Množstvo individuálnych reštituentov čaká na vysporiadanie pôdy aj desat'ročia. Často pritom dochádza k skupovaniu nárokov reštituentov investormi, ktorí majú silnejšiu vyjednávaciu pozíciu a vedia urýchlit' reštitučný proces (často nejasné pozadie firiem či podozrivé prevody pôdy).

- Aktívny prístup samosprávy. Ojedinele je vznik vel'kých developerských projektov obmedzovaný proaktívnym prístupom samosprávy. Príkladom je obec Lozorno, ktorá doposial' neumožnila realizovat' väčšie developerské projekty a rozvoj $\mathrm{v}$ tejto obci sa realizuje prevažne individuálnou výstavbou rodinných domov. Opačným príkladom je obec Chorvátsky Grob, kde v počiatkoch benevolentný prístup samosprávy k investorom umožnil vznik neregulovanej rezidenčnej výstavby (Šveda a Šuška 2014). V tejto súvislosti treba upozornit' aj na úlohu, ktorú zohráva sút'aživost' o investície medzi jednotlivými samosprávami. Couch et al. (2007) si všímajú, že čím nezávislejšie postavenie má samospráva, tým výraznejšia sút'aživost' bude medzi jej priestorovými jednotkami, ktoré $\mathrm{v}$ snahe prilákat' investorov (nových rezidentov) budú znižovat' svoje nároky a umožňovat' investorom výstavbu (prinášajúcu množstvo dodatočných nákladov).

\footnotetext{
${ }^{6}$ Ukážka z webovej stránky investora: „Záhorské sady sú jednou z mála lokalít v Bratislave, kde sú v ponuke pozemky s nadštandardnou výmerou. Vd’aka regulatívom platným pre túto oblast', ktoré predpisujú odstupy domov od hranice pozemkov, výšku či sklon strechy, tu nehrozí ani prehustenie zástavby, tak ako je to v iných prímestských častiach Bratislavy“ (www.zahorskesady.sk).
} 
GEOGRAFICKÝ ČASOPIS / GEOGRAPHICAL JOURNAL 70 (2018) 3, 231-258

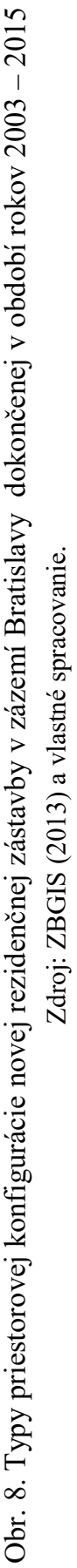




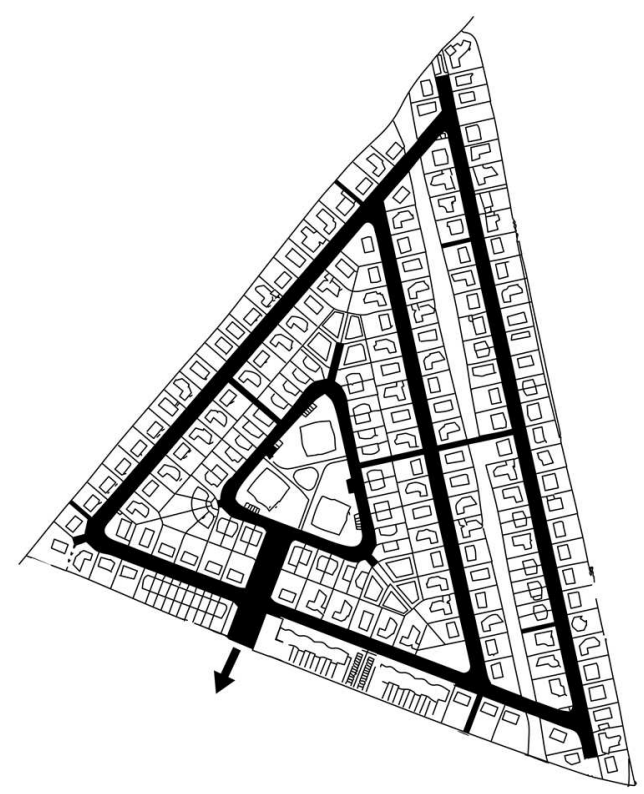

Obr. 9. Príklad suburbia napojeného na cestnú siet’ len v jednom bode (lokalita Triangel, Chorvátsky Grob)

Zdroj: Mapový portál katastra nehnutel'ností ÚGKK SR (2013), upravené.

\section{DISKUSIA A ZÁVEREČNÉ POZNÁMKY}

Akcelerácia suburbánneho rozvoja $\mathrm{v}$ zázemí Bratislavy prináša do pôvodne prehl'adného a prevažne monofunkčného vidieckeho prostredia nové priestorové formy, ktorých základné parametre sme sa pokúsili v príspevku charakterizovat'.

Analýzou priestorového usporiadania novej rezidenčnej výstavby v zázemí Bratislavy sme poukázali na formovanie koncentrovaných a priestorovo oddelených suburbií, ktoré narúšajú kompaktný charakter pôvodnej rezidenčnej zástavby. Vznik týchto sídelných útvarov však nemôžeme vnímat' len ako výsledok stratégie developerov (čo najväčší počet bytových jednotiek na plochu), ale aj preferencií nových suburbánnych rezidentov, ktorí uprednostňujú izolovaný charakter rezidenčných projektov. Tieto tendencie môžeme vnímat' aj ako manifestáciu individualizmu a fenoménov postsocialistickej spoločnosti (cf. Hirt 2012). Pre priestorový vzorec (pattern) suburbií v zázemí Bratislavy je charakteristický pragmatizmus bývania, funkčná účelovost' a minimalizovanie rozsahu nerezidenčných plôch? V tejto súvislosti vystupuje nasledujúci paradox. Formovanie koncentrovaných rezidenčných zón (ucelených projektov developerov) prináša možnost', ako vybudovat' kvalitné prímestské prostredie, ktoré by sa inak len zložito vytváralo individuálnou výstavbou (uličná zeleň, verejné priestory a uličný mobiliár). Charakter väčšiny suburbií v zázemí Bratislavy však nasvedčuje, že príležitosti na vytváranie kvalitného urbanizmu sa využívajú len vel'mi ojedinele.

\footnotetext{
${ }^{7}$ Príkladom sú chýbajúce chodníky, ktoré nie sú nepotrebné pre l’udí využívajúcich individuálnu automobilovú dopravu. Takisto rozsah sídelnej zelene je minimalizovaný len na nevyhnutnú „dekoráciu“, tak aby neprinášala zvýšené nároky na údržbu.
} 
a)

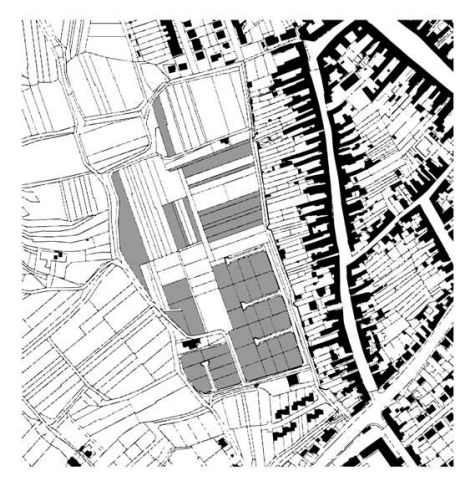

c)

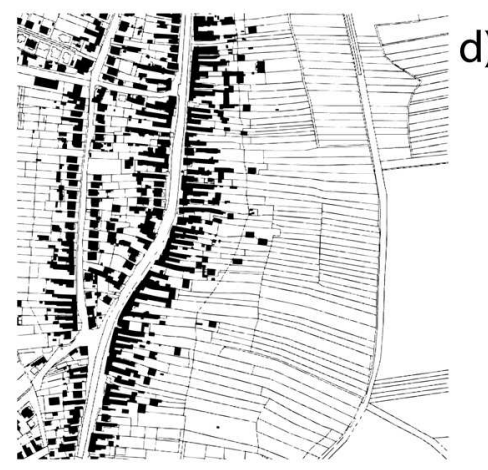

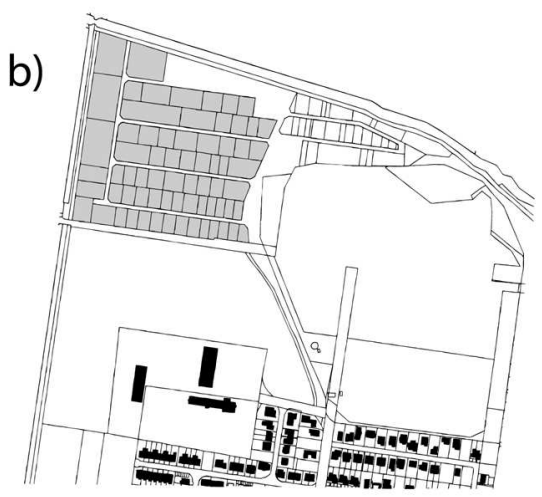

d)

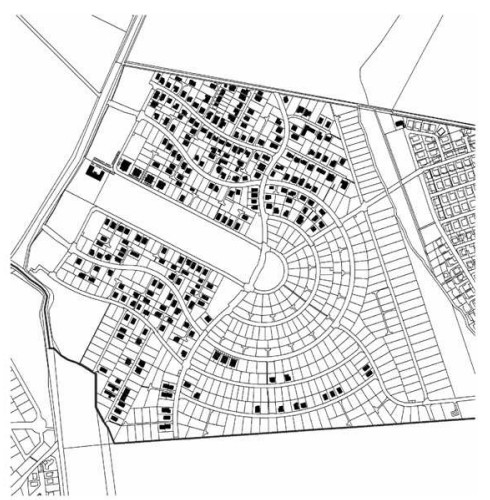

Obr. 10. Transformácia zázemia Bratislavy na vybraných príkladoch z Katastra nehnutel'ností

a) Blížiace sa zastavanie vinohradov v meste Svätý Jur. Investori postupne skupujú jednotlivé parcely vinohradov (šedá farba), ktoré sú v zapätí preklasifikované na kategóriu trvalých trávnatých porastov. Po scelení lokality sa môže začat' výstavba. b) Rozparcelované územie v extraviláne mesta Stupava (šedá farba), na ktorého mieste sú v súčasnosti nevyužívané pasienky (trvalé trávnaté porasty) a ktoré nenadväzuje na existujúcu sídelnú štruktúru. Vlastnícka štruktúra aj výmery parciel naznačujú, že ide o investíciu do areálov s lacnou pôdou, ktorá čaká na budúce zhodnotenie. Kým v minulosti sa vidiecke sídla vytvárali prirodzenou adíciou nových domov na okraji intravilánu, v súčasnosti je sídelná štruktúra vtlačená do územia $\mathrm{v}$ d’alekom predstihu, ked'sa územie aktívne pol’nohospodársky využíva. c) Parcelácia v katastrálnom území Mást (čast' Stupava). Rezidenčnej výstavbe v bezprostrednej nadväznosti zabraňuje častokrát rozdrobená vlastnícka štruktúra parciel. Bývalé „záhumienky“ nie sú v súčasnosti pol'nohospodársky využívané (ich využitie nie je nevyhnutné pre potravinová sebestačnost' či úsporu nákladov) a vytvárajú spustnuté územie, ktoré nie je pre investorov atraktívne (náročné scel'ovanie parciel). d) Rozparcelovanie územia v prímestskej obci Slovenský Grob po „vzore“ severoamerických predmestí so snahou o vytvorenie akéhosi centrálneho priestoru, ktorý však podla vizualizácie investora nemá slúžit' ako park, ale má byt' priestorom pre bytové domy.

Zdroj pre všetky obrázky: Mapový portál katastra nehnutel'ností ÚGKK SR, upravené. 
Prímestské prostredie však môže mat' iné kvality a parametre než urbánny priestor a z hl'adiska celkovej efektivity využitia územia mu môže len t'ažko konkurovat'. Treba však zdôraznit', že súčasný charakter suburbií v zázemí Bratislavy sa z pohl'adu základného parametra - hustoty zal'udnenia - príliš neodlišuje od prostredia pôvodnej vidieckej zástavby. Hoci nová suburbánna zástavba predstavuje dramatickú vizuálnu premenu vidieckych obcí, neprináša výraznejší nárast hustoty zal'udnenia. Ak uvažujeme o suburbanizácii ako o procese pretvárajúcom vidiecke prostredie na (pred)mestské, tak potom by sme mohli očakávat', že v zázemí mesta sa budú formovat' štruktúry s atribútmi viac mestskými ako vidieckymi. $Z$ hl'adiska hustoty zal'udnenia súčasných bratislavských suburbií však len t’ažko môžeme hovorit' o vytváraní ,predmestia“, ktoré by bolo prirodzeným gradientom medzi mestskou a vidieckou formou zástavby. Skúsenosti z vývoja západoeurópskych predmestí pritom jednoznačne hovoria, že zvyšovanie hustoty zal'udnenia (tzv. compact sprawl) umožňuje etablovanie rozmanitejších funkcií a posilňuje tak sebestačnost' suburbií aspoň v niektorých aspektoch (Haughey 2005). Systematické zvyšovanie hustoty zástavby však naráža na platné stavebné regulatívy. Normy pre odstupy stavieb, zastavanost' pozemkov či umiestnenie domu na parcele totiž podporujú vytváranie nekompaktných a rozvol'nených štruktúr (Hnilička 2013).

Uvedené zistenia dokumentujú, že uvažovanie nad hustotou zal'udnenia v kontexte rozlohy katastrálnych území (Hudec a Tóth 2013) či využitia zeme v súvislosti s databázou ÚHDP nezohl'adňuje reálne zmeny v prostredí suburbanizovaných obcí. Z hl'adiska analýzy a exaktného hodnotenia zmien $\mathrm{v}$ suburbanizovaných obciach je vhodnejšie pracovat's reálnym stavom zástavby (z leteckého alebo satelitného snímkovania), ktoré je bližšie realite.

$\mathrm{V}$ ostatných rokoch môžeme v zázemí Bratislavy pozorovat' tendencie, ktoré do monofunkčných rezidenčných zón prinášajú náznaky sofistikovanejšieho urbanizmu a nové služby. V plánoch nových rezidenčných zón sa objavujú aj verejné priestory, materské centrá, športoviská či kaviarne. Investori lákajú klientov na „pešiu dostupnost"“, ,dostatok občianskej vybavenosti““ alebo na „spojenie vidieckeho pokoja s benefitmi mesta“. Pre umelé vytváranie „mestských“ prvkov v suburbiách sa vžilo pomenovanie „náhradný urbanizmus“ (ersatz urbanism). Nevytvára skutočné mestské prostredie, ale len imituje jeho aspekty prostredníctvom polyfunkčných budov s kaviarňami, pešími zónami, parkmi a cyklochodníkmi. Kým doteraz predmestia tvorené na princípoch nového urbanizmu propagovali ideál vidieckeho alebo malomestského bývania, projekty ersatz urbanizmu propagujú (vel'ko)mestský život (Suchý 2016). Treba však upozornit’ že vytváranie mestského vzhl'adu nie je to isté ako vytváranie mesta. Vel'ké mestá sú vo svojej podstate kozmopolitné s nepredvídatel'nou trajektóriou zmien. Na rozdiel od tradičného urbánneho prostredia, nové „mestské centrác ${ }^{68} \mathrm{v}$ suburbiu sú vytvárané ad hoc a neposkytujú priestor pre všetky vrstvy obyvatel'ov. Nie sú teda predurčené pre diverzitu, takú typickú pre skutočné mestské prostredie. Nakol'ko sa uvedené trendy „náhradného“ urbanizmu prejavujú v zázemí Bratislavy, je ešte t’ažké plnohodnotne posúdit'. Je však pravdepodobné, že monofunkčné využívanie plôch, ktorého koncepty boli už

\footnotetext{
${ }^{8}$ Termín „ersatz urbanism“ si netreba zamieňat’ s pojmom „edge cities“, ktoré vznikajú ako nové jadrá v sídelnom priestore zázemia vel'komiest a ich charakteristickým rysom je koncentrácia rôznorodejších funkcií (bývanie, maloobchod, kancelárie, sklady, univerzitné areály a pod.), čím vytvárajú relatívne sebestačné centrá v rámci priestorovej štruktúry metropolitných areálov. Na rozdiel od spomínaného „ersatz urbanizmu“, tieto nové centrálne lokality vznikajú organicky ako dôsledok výhodnej lokalizácie, napr. pri uzlových bodoch dial'ničnej siete.
} 
dávno prekonané a ktoré nereflektuje potreby súčasnej spoločnosti, sa bude transformovat' smerom k väčšej polyfunkcii a multinodalite.

Téma nekontrolovatel'ného sídelného a populačného rastu sa $\mathrm{z}$ akademického prostredia dostáva čoraz viac do popredia celospoločenského diskurzu, v ktorom sa suburbiá prirovnávajú k horizontálne usporiadaným sídliskám (,,paneláky naležato"), čím sa poukazuje na ich monofunkčnost' a nedostatočnú vybavenost'. Fragmentácia novej zástavby na množstvo relatívne samostatných rezidenčných lokalít a nerešpektovanie priestorových atribútov pôvodnej sídelnej siete vhodne vystihuje aj pojem „sídelná kaša“" (Hnilička 2012). Toto nesúrodé prostredie býva často kritizované vo viacerých aspektoch, pričom sa zdôrazňuje najmä jeho monofunkčnost', priestorová a energetická neefektívnost', sociálna homogénnost' alebo chýbajúca identita. Uvedené dynamické zmeny prímestskej krajiny a nové fenomény, ktoré prináša suburbánny rozvoj, prispeli k prvým reakciám v legislatívnej oblasti. Príkladom je zavedenie „rozvojového poplatku“9 či novelizácia zákona o využívaní pol'nohospodárskej pôdy ${ }^{10}$. Bez prehodnotenia súčasných stavebných regulatívov (stavebný zákon z roku 1976) a chýbajúcich efektívnych nástrojov (a ich účinným využívaním) územného plánovania však nedokážeme dostatočne reagovat' na aktuálne sídelné trendy a vytvárat' podmienky pre vznik životaschopných sídiel. Izolovaním parametrov sídelnej morfológie však dostávame potrebný nástroj a pragmatickú reakciu na súčasnú územno-plánovaciu realitu na Slovensku. Sledovanie aspektov sídelnej morfológie $\mathrm{v}$ urbánnom a suburbánnom prostredí nám môže pomôct' odhalit' a porozumiet' dlhodobým dôsledkom nových sídelných foriem na vývoj priestorovej organizácie spoločnosti.

Tento príspevok bol podporovaný Agentúrou na podporu výskumu a vývoja na základe Zmluvy č. APVV-16-0462 a grantom VEGA č. 0096/16.

\section{LITERATÚRA}

ANDERSON, W. P., KANAROGLOU, P. S., MILLER, E. J. (1996). Urban form, energy and the environment: a review of issues, evidence and policy. Urban Studies, 33, 7-35.

ANTROP, M. (2004). Landscape change and the urbanisation process in Europe. Landscape and Urban Planning, 67, 9-26.

BALDASSARE, M., WILSON, G. (1995). More trouble in paradise: urbanization and the decline in suburban quality-of-life ratings. Urban Affairs Review, 30, 690-708.

BATTY, M., KIM, K. S. (1992). Form follows function: reformulating urban population density functions. Urban Studies, 29, 1043-1070.

BATTY, M., LONGLEY, P. A. (1986). The fractal simulation of urban structure. Environment and Planning $A, 18,1143-1179$.

BERGHAUSER, M., HAUPT, P. (2004). The spacemate: density and the typomorphology of the urban fabric. Nordisk A rkitekturforskning Number, 4, 55-68.

BEZÁK, A. (2014). Funkčné mestské regióny na Slovensku v roku 2001. In Lauko, V., ed. Regionálne dimenzie Slovenska. Bratislava (Univerzita Komenského v Bratislave), pp. 169-198.

\footnotetext{
${ }^{9}$ Zákon o miestnom poplatku za rozvoj umožňuje obciam pýtat' si od investorov a developerov poplatok až do výšky $35 € / \mathrm{m}^{2}$ zastavanej plochy. Získané finančné zdroje majú pomôct' samospráve dobudovat' chýbajúcu infraštruktúru a občiansku vybavenost'.

${ }^{10}$ Uvedená novelizácia z roku 2014 mala priniest' lepšiu ochrana pol’nohospodárskej pôdy pred neoprávnenými zábermi na nepol'nohospodárske použitie. Po novelizácii je v prípade zmien viníc potrebné odborné stanovisko Ústredného kontrolného a skúšobného ústavu pol'nohospodárskeho a stanovisko dotknutého orgánu územnej samosprávy obsahujúce zhodnotenie historických súvislostí a zámerov regionálneho rozvoja. Pribudla povinnost' navrhovatel'a zaplatit' odvod za odňatie pol'nohospodárskeho druhu pozemku vinica.
} 
BORÉN, T., GENTILE, M. (2007). Metropolitan processes in post-communist states: an introduction. Geografiska Annaler: Series B, Human Geography, 89, 95-110.

CEBECAUEROVÁ, M., MADAJOVÁ, M. (2015). Od analýzy priestorovej štruktúry $\mathrm{k}$ identifikovaniu trendov vo vývoji pol’nohospodárskej krajiny v zázemí Bratislavy. Geografický časopis, 67, 127-148.

CERVERO, R., KOCKELMAN, K. (1997). Travel demand and the 3ds: density, diversity, and design. Transportation Research Part D: Transport and Environment, 2, 199-219.

CLARK, C. (1951). Urban population densities. Journal of the Royal Statistical Society (Series A), 114, 490-496.

CLIFF, A. D., ORD, J. K. (1973). Spatial Autocorrelation. London (Pion).

COUCH, C., LEONTIDOU, L., PETSCHEL-HELD, G., eds. (2007). Urban sprawl in Europe: landscapes, land-use change and policy. Oxford (Blackwell Publishing Ltd.).

De CLERCQ, E. M., De WULF, R., Van HERZELE, A. (2007). Relating spatial pattern of forest cover to accessibility. Landscape and Urban Planning, 80, 14-22.

DIVINSKÝ, B. (2000). Koncepcia morfologického mesta a jej aplikácia na Bratislavu. Urbánne a krajinné štúdie, 3, 39-47.

EEA (2006). Urban sprawl in Europe: the ignored challenge, EEA Report No 10/2006. Copenhagen (European Environment Agency).

EWING, R. (1994). Characteristics, causes, and effects of sprawl: a literature review. Environmental and Urban Issues, 21, 1-15.

EWING, R. CERVERO, R. (2010). Travel and the built environment. Journal of the American Planning Association, 76, 265-294.

EWING, R., PENDALL, R., CHEN, D. (2002). Measuring sprawl and its impact. Smart Growth America, [Online]. Dostupné na: http://www.smartgrowthamerica.org/ sprawlindex/MeasuringSprawl.PDF [cit: 30.5.2018].

FERANEC, J. (2008). Krajinná pokrývka a využitie krajiny Slovenska v kontexte národnej štatistiky a dát CORINE Land Cover. Acta Geographica Universitatis Comenianae, 50, $135-144$.

FERANEC, J., OŤAHEL, J. (2008). Land cover changes in Slovakia in the period 1970 2000. Geografický časopis, 60, 113-125.

FISHMAN, R. (1987). Bourgeis utopias: the rise and fall of suburbia. New York (Basic Books).

FORSYTH, A., OAKES, J. M. SCHMITZ, K. HEARST, M. (2007). Does residential density increase walking and other physical activity? Urban Studies, 44(4), 679-697.

FRENKEL, A., ASHKENAZI, M. (2008). Measuring urban sprawl. Environment and Planning, B: Planning and Design, 35, 56-79.

GAJDOS, P., MORAVANSKÁ, K. (2011). Suburbanizácia a jej podoby na Slovensku. Bratislava (Veda).

GALČANOVÁ, L. (2013). Svoboda, soukromí a bezpečí: nové hraniční prostory v naracích obyvatel vybraných brněnských předměstí. In Ouředníček, M., Špačková, P., Novák, J., eds. Sub Urbs: krajina, sídla a lidé. Praha (Academia), pp. 200-233.

GALSTER, G., HANSON, R., RATCLIFFE, M. R., WOLMAN, H., COLEMAN, S., FREIHAGE, J. (2001). Wrestling sprawl to the ground: defining and measuring an elusive concept. Housing Policy Debate, 12, 681-717.

GEHL, J., JOHANSEN KAEFER, L., REIGSTAD, S. (2006). Close encounters with buildings. Urban Design International, 11, 29-47.

GKÚ (2014).Úhrnné hodnoty druhov pozemkov (ÚHDP) 2002-2013. Bratislava (Geodetický a kartografický ústav).

GKÚ (2013). Základná báza údajov pre geografický informačný systém (ZBGIS). Bratislava (Geodetický a kartografický ústav).

GLOCK, B., HÄUSSERMANN, H., KELLER, C. (2007). Social and spatial consequences of the restitution of real estate. In Stanilov, K., ed. The post-socialist city, the GeoJournal Library 92. Dordrecht (Springer), pp. 191-214. 
GORDON, P., RICHARDSON, H. (1989). Gasoline consumption and cities - a reply. Journal of the American Planning Association, 55, 342-346.

GRAHN, P., STIGSDOTTER, U. (2003). Landscape planning and stress. Urban Forestry \& Urban Greening, 2, 1-18.

GKÚ (2014). Úhrnné hodnoty druhov pozemkov (ÚHDP) 2002-2013. Bratislava (Geodetický a kartografický ústav Bratislava).

HANUŠIN, J., CEBECAUEROVÁ, M., HUBA, M., IRA, V., LACIKA, J., MADAJOVÁ, M., OŤAHEL, J., PODOLÁK, P. (2013). Kultúrna krajina podmalokarpatského regiónu. Bratislava (Geografický ústav SAV).

HAUGHEY, R. M. (2005). High-density development: myth and fact. Washington, DC (Urban Land Institute).

HILLIER, B., PENN, A., HANSON, J., GRAJEWSKI, T., XU, J. (1993). Natural movement: or, configuration and attraction in urban pedestrian movement. Environment and Planning B: Planning and Design, 20, 29-66.

HIRT, S. (2007). Suburbanizing Sofia: characteristics of post-socialist Peri-urbanchange. Urban Geography, 28, 755-780.

HIRT, S. (2012). Iron curtains: gates, suburbs and privatization of space in the postsocialist city. Oxford (Wiley-Blackwell).

HNILIČKA, P. (2012). Sídelní kaše: otázky k suburbánní výstavbě kolonii rodinných domi. Brno (Host).

HNILIČKA, P. (2013). Verejné prostranství v době rozmachu sídelní kaše. In Ouředníček, M., Špačková, P., Novák, J., eds. Sub Urbs: krajina, sídla a lidé. Praha (Academia), pp.256-288.

HÖRNSTEN, L., FREDMAN, P. (2000). On the distance to recreational forests in Sweden. Landscape and Urban Planning, 51, 1-10.

HUDEC, R., TÓTH, V. (2013). Gradient hustoty zal'udnenia a jeho zmeny v regiónoch najväčších miest Slovenskej republiky. Geographia Cassoviensis, 7, 55-68.

INGRAM, G. (1998). Patterns of metropolitan development: what have we learned? Urban Studies, 35, 1019-1035.

INOSTROZA, L. (2014). Measuring urban ecosystem functions through "Technomass" a novel indicator to assess urban metabolism. Ecological Indicators, 42, 10-19.

IŠTOK, R., KLAMÁR, R. (2005). Geografické aspekty vytvárania spoločných obecných úradov v kontexte mikroregionálnej medziobecnej spolupráce. Acta Facultatis Rerum Naturalium Universitatis Comenianae, Geographica, Supplementum,3, 221-228.

KOPECKÁ, M, ROSINA, K. (2014). Identifikácia zmien urbanizovanej krajiny na báze satelitných dát s vel’mi vysokým rozlíšením (VHR): záujmové územie Trnava. Geografický časopis, 66, 247-267.

KOPECKÁ, M., ROSINA, K., OŤAHEL, J., FERANEC, J., PAZÚR, R., NOVÁČEK, J. (2015). Monitoring dynamiky zastavaných areálov. Geographia Slovaca, 30. Bratislava (Geografický ústav SAV).

LEE, C., MOUDON, A. V. (2006). The 3Ds + R: quantifying land use and urban form correlates of walking. Transportation Research Part D, 11, 204-215.

LEETMAA, K., TAMMARU, T., ANNISTE, K. (2009). From priority-led to market-led suburbanisation in a post-communist metropolis. Tijdschrift voor Economische en Sociale Geografie, 100, 436-453.

NEWMAN, P., KENWORTHY, J. (1989). Cities and automobile dependence: an international sourcebook. Aldershot (Gower Publishing).

NOVOTNÝ, L. (2011). Funkčné mestské regióny najväčších slovenských miest v modeloch urbánneho vývoja. Geographia Cassoviensis, 5, 93-102.

NOVOTNÝ, L. (2016). Urban development and migration processes in the urban region of Bratislava from the post-socialist transformation until the global economic crisis. Urban Geography, 37, 1009-1029.

NUISSL, H., RINK, D. (2005). The 'production' of urban sprawl in eastern Germany as a phenomenon of post-socialist transformation. Cities, 22, 123-134. 
ONDOŠ, S., MILÁČKOVÁ, M., BELUŠÁK, L., RUSNÁK, J., KUSENDOVÁ, D. (2017). Spatial development of residential market in Bratislava region. Geografický časopis, 69, 95-112.

O'SULLIVAN, D., UNWIN, D. (2002). Geographic information analysis. Hoboken (Wiley).

OUREDNIČEK, M. (2002). Suburbanizace v kontextu urbanizačního procesu. In Sýkora, L., ed. Suburbanizace a její sociální, ekonomické a ekologické di̊sledky. Praha (Ústav pro ekopolitiku), pp. 39-54.

OUREDNÍČEK, M. (2007). Differential suburban development in the Prague urban region. Geografiska Annaler: Human Geography, 89B 2, 111-125.

OUŘEDNIČEK, M., POSPÍŠILOVÁ, L. (2016). Editorial: urban dynamics and neighbourhood change in cities after transition. Sociologický časopis, 52, 787-794.

OUŘEDNÍČEK, M., ŠPAČKOVÁ, P. (2013). Teoretické př́ístupy a současná témata výzkumu suburbanizace. In Oưredníček, M., Špačková, P., Novák, J., eds. Sub Urbs: krajina, sídla a lidé. Praha (Academia), pp. 13-36.

PAZÚR, R., FERANEC, J., ŠTYCH, P., KOPECKÁ, M., HOLMAN, L. (2017). Changes of urbanised landscape identified and assessed by the urban atlas data: case study of Prague and Bratislava. Land Use Policy, 61, 135-146.

PAZÚR, R., OŤAHEL', J., MARETTA, M. (2012). Analýza priestorovej heterogenity tried krajinnej pokrývky v odlišných prírodných podmienkach. Geografie, 117, 371-394.

PODOLÁK, P. (2007). Geografické aspekty suburbanizácie a priestorový pohyb obyvatel'stva. Životné prostredie, 41, 298-302.

POTOČNÝ, T. (2006). Lidé na okraji. Př́padová studie satelitního městečka. IVRIS Working Papers 06/01. Brno (Institut pro výzkum reprodukce a integrace společnosti. Fakulta sociálních studií Masarykovy univerzity).

PTÁČEK, P. (2002). Suburbanizace v USA a Německu: zdroj inspirace i poučení. In Sýkora, L., ed. Suburbanizace a jeji sociální, ekonomické a ekologické důsledky. Praha (Ústav pro ekopolitiku), pp. 55-79.

PUTNAM, R. D. (2000). Bowling alone: the collapse and revival of A merican community. New York (Simon \& Schuster).

SAI, YU-HSIN (2005). Quantifying urban form: compactness versus 'Sprawl'. Urban Studies, 42, 141-161.

SHIMEK, P. (1996). Household motor vehicle ownership and use: how much does residential density matter? Transportation Research Record, 1552, 120-125.

SHORTRIDGE, A. (2007). Practical limits of Moran's autocorrelation index for raster class maps. Computers, Environment and Urban Systems, 31, 362-371.

SLAVIK, V., GRÁC, R., M. KLOBUČNÍK, M., KOHUTOVÁ, M. (2011). Development of Suburbanization of Slovakia on the example of the Bratislava region. In Marszal, T., ed. Urban regions as engines of development. Warsaw (Polish Academy of Science, Committee for Spatial Economy and Regional Planning), pp. 35-58.

STÅHLE, A. (2008). Compact sprawl: exploring public open space and contradictions in urban density. Dissertation Thesis, KTH Architecture and the Built Environment, Stockholm.

STANILOV, K. (2003). Introduction: postwar growth and suburban development patterns. In Stanilov, K., Sheer, B. C., eds. Suburban form: an international perspective. New York (Routledge), pp. 1-12.

STANILOV, K., ed. (2007). Housing trends in Central and Eastern European cities during and after the period of transition. In The Post-socialist City. The GeoJournal Library 92, (Springer), pp. 173-190.

STANILOV, K. SHEER, B.C., eds. (2003). Suburban form: an international perspective. London (Routledge).

STANILOV, K., SÝKORA, S. (2014). Confronting suburbanization: urban decentralization in postacialist Central and Eastern Europe. Chichester (Wiley). 
SUCHÝ, D. (2016). Predmestia vyšli z módy, chcú sa stat' mestom. Trend.sk, [Online]. Dostupné na: https://reality.etrend.sk/byvanie/predmestia-vysli-z-mody-chcu-sa-statmestom.html [cit: 30.5.2017].

SÝKORA, L., STANILOV, K. (2014). The challenge of postsocialist suburbanization. In Stanilov, K., Sýkora, L., eds. Confronting suburbanization. Urban decentralization in postsocialist Central and Eastern Europe. Chichester (Wiley-Blackwell), pp. 1-32.

ŠÚ SR (2016). Bytová výstavba 2003 - 2015. Bratislava (Štatistickú úrad SR).

ŠVEDA, M. (2009). Priestorová štruktúra rezidenčnej suburbanizácie v prímestskej zóne Bratislavy. Acta Geographica Universitatis Comenianae, 53, 169-181.

ŠVEDA, M. (2011). Suburbanizácia v zázemí Bratislavy z hladiska analýzy zmien krajinnej pokrývky. Geografický časopis, 63, 155-173.

ŠVEDA, M. (2014). Bytová výstavba v zázemí vel'kých slovenských miest v kontexte suburbanizácie a regionálnych disparít. In Michálek, A., Podolák, P., eds. Regionálne a priestorová disparity na Slovensku, ich vývoj v ostatnom desat'ročí, súčasný stav a konzekvencie. Bratislava (Geografický ústav SAV), pp. 173-195.

ŠVEDA, M. (2016). Život v Bratislavskom suburbiu: prípadová štúdia mesta Stupava. Sociológia, 48,139-171.

ŠVEDA, M., MADAJOVÁ, M., PODOLÁK, P. (2016). Behind the differentiation of suburban development in the hinterland of Bratislava, Slovakia. Sociologický časopis, 52, 893-926.

ŠVEDA, M., PODOLÁK, P. (2014). Fenomén neúplnej evidencie migrácie v suburbánnej zóne (na príklade zázemia Bratislavy). Geografický časopis, 66, 115-132.

ŠVEDA, M., ŠUŠKA, P. (2014). K príčinám a dôsledkom živelnej suburbanizácie: príklad obce Chorvátsky Grob. Geografický časopis, 66, 225-246.

TALEN, E. (2003). Measuring urbanism: issues in smart growth research. Journal of Urban Design, 8, 195-215.

TAMMARU, T. (2001). Suburban growth and suburbanisation under central planning: the case of Soviet Estonia. Urban Studies, 38, 1341-1357.

TAMMARU, T., LEETMAA, K., SILM, S., AHAS, R. (2009). Temporal and spatial dynamics of the new residential areas around Tallinn. European Planning Studies, 17, 423439.

TCRP (2002). Costs of sprawl - 2000. Transit Cooperative Research Program. Report 74. Washington, D.C. (Transportation Research Board - National Research Council, National Academy Press).

TORRENS, P. M., ALBERTI, M. (2000). Measuring sprawl. (CASA Working Papers 27). London (Centre for Advanced Spatial Analysis (UCL).

TSAI, YU-HSIN (2005). Quantifying urban form: compactness versus 'sprawl'. Urban Studies, 42(1), 141-161.

TURNER, M.G. (1989). Landscape ecology: the effect of pattern on process. Annual Review of Ecology and Systematics, 20, 171-197.

ÚGKK SR (2013). Základná báza údajov pre geografický informačný systém (ZBGIS) Btratislava (Úrad geodézie kartografie a katastra SR).

Van Den BERG, L., BRAUM, E., Van WIDEN, W. (2001). Growth cluster in European metropolitan cities. Aldershot (Burlinghton, AshGate).

Van HERZELE, A. WIEDEMANN, T. (2003). A monitoring tool for the provision of accessible and attractive urban green spaces. Landscape and Urban Planning, 63, 109-126.

VAUGHAN, L., GRIFFITHS, S., HAKLAY, M., JONES, C. E. (2009). Do the suburbs exist? Discovering complexity and specificity in suburban built form. Transactions of the Institute of British Geographers, 34, 475-488.

ZUBRICZKÝ, G. (2010). Suburbanizácia Bratislavy. In Hardi, T, Lados, M., Toth, K., eds. Slovensko-mad'arská aglomerácia v okolí Bratislavy. Györ-Samorín (Stredisko regionálnych výskumov Mad’arskej akadémie vied, Fórum inštitút pre výskum menšín).

Zdroj údajov:

Mapový portál katastra nehnutel'ností ÚGKK SR, www.mapka.gku.sk 


\author{
Martin Šveda, Róbert Pazúr
}

\title{
SPATIAL FORMS OF RESIDENTIAL SUBURBANIZATION IN THE HINTERLAND OF BRATISLAVA
}

The paper focuses on the phenomenon of suburban development from the perspective of spatial morphology - an approach to which Slovak literature has not paid much attention. The objective of this paper is to outline the spatial configuration of residential suburbanization in the hinterland of Bratislava with a specific view on the relation of spatial arrangement (pattern) of the housing construction to the key indicators characterizing the extent and intensity of the suburbanization processes (migration rate, migrants' origin, housing construction, etc.). The paper, set in the field of urban morphology, explores the spatial conditions of suburban development by looking at measures of density, spatial configuration and accessibility. Through selected examples, the paper uncovers the mechanism of spatial configurations (territorial regulations, morphology of the territory, different municipal strategies, distance from Bratislava city centre, real estate prices, etc.).

The timeframe is characterized by the period $2003-2012$ and the paper works with the settlement layer from the ZBGIS database (the basic data base for the geographic information system), aerial photographs as well as from cadastral maps. To reveal the nature of suburban development patterns, we used an indicator of spatial arrangement, which is represented by the measure of spatial autocorrelation - Morans' Index (Cliff and Ord 1973). A perfectly concentrated arrangement of units would give a value that is close to 1. A randomly dispersed arrangement of units would give a Moran's Index value that is close to 0 . We can thus distinguish highly concentrated large-scale development sites from the more dispersed development of individual constructors.

In the first step the paper examines the density of housing construction on different scales. On a regional scale the results show that although suburban development represents a dramatic visual transformation of the rural environment, there is no significant increase in the population density. On the local scale the paper focuses on the development of suburbia, which is predominantly formed as an ad hoc residential area with a relatively concentrated housing construction and sharp boundaries. This spatial concentration can be simplistically identified through spatial autocorrelation (Morans' Index). It is obvious that the concentrated forms of construction (large-scale residential projects) dominate mainly in the municipalities in the city's immediate hinterland, while the more distant parts are characterized by rather dispersed development. In the following section the paper focuses on the identifying of basic spatial configurations of suburban development in the hinterland of Bratislava. The investigation reveals a number of concentrated development sites separated from the former settlement structure by undeveloped areas. This greenfield development brings a set of serious challenges for urban planning and management.

Understanding the morphogenesis of new settlement structures in urban hinterlands plays a key role in identifying the social, economic and environmental impacts of suburbanization. In fact, this is a vast unexplored field that needs further attention in urban studies and urban morphology in particular. 